\title{
Realismus hudebního divadla Waltera Felsensteina - pravda, nebo mýtus?
}

\section{Realism of Walter Felsenstein's Music Theatre: Truth or Myth?}

\author{
Šárka Havlíčková Kysová, Helena Spurná
}

\begin{abstract}
Abstrakt
Studie se zabývá konceptem hudebního divadla, jenž je spjat s tvorbou významného německého operního režiséra Waltera Felsensteina (1901-1975). Východiskem se stala monumentální monografie Borise Kehrmanna Vom Expressionismus zum verordneten "Realistischen Musiktheater". Walter Felsenstein - Eine dokumentarische Biographie 1901 bis 1951 (2015), podrobující zásadní revizi představu o Felsensteinovi jako o režisérovi, který ve svých operních inscenacích realizoval přístupy realismu jakožto uměleckého stylu. Přítomná studie si neklade za cíl pouhou sumarizaci základních tezí Kehrmannovy knihy. Ohlas a recepce Felsensteinových operních režií v zahraničí, zejména pak v zemích tzv. východního bloku, autorky přivedly k nutnosti přezkoumat situaci v domácím kontextu, resp. v českých operních divadlech. Záměrem bylo položit si otázku, jak byl Felsensteinův vklad do inscenování opery přijímán v českém prostředí a zda tu našel své stoupence.
\end{abstract}

\section{Klíčová slova}

Walter Felsenstein, Komická opera v Berlíně, hudební divadlo, operní režie, realismus, socialistický realismus, české operní divadlo

\begin{abstract}
The study deals with Music Theatre of Walter Felsenstein (1901-1975), a renowned German opera director of the $20^{\text {th }}$ century. It is based on the seminal monograph of estimable size by Boris Kehrmann, Vom Expressionismus zum verordneten "Realistischen Musiktheater". Walter Felsenstein - Eine dokumentarische Biographie 1901 bis 1951 (2015) that revisits Felsenstein's directorial style and questions the presumption that he employed Realistic techniques in his operatic productions. However, the study does not merely summarize the issues introduced by Kehrmann. Since Felsenstein's directorial style gained acceptance over the countries of the so-called Eastern Bloc, reception of Felsenstein's work in Czech opera is the subject of inquiry, exploring the alleged influences and supporters of the director.
\end{abstract}

\section{Keywords}

Walter Felsenstein, Komische Oper Berlin, Music Theatre, opera direction, Realism, Social Realism, Czech opera theatre

Studie vznikla v rámci grantového projektu GA15-06548S "Generace režiséra Miloše Wasserbauera a progresivní dramaturgie v opeře Státního divadla v Brně". 
V nedávné době způsobila $\mathrm{v}$ německém operním prostředí a v tamějších operně vědných kruzích značný rozruch více než 1300 stránková kniha Vom Expressionismus zum verordneten „Realistischen Musiktheater“. Walter Felsenstein - Eine dokumentarische Biographie 1901 bis 1951 (Od expresionismu k nařízenému „realistickému hudebnímu divadlu“. Walter Felsenstein - dokumentární biografie 1901-1951). ${ }^{1}$ Její autor, publicista a v nynější době dramaturg Státního divadla v Karlsruhe Boris Kehrmann (1963) se po čtyřiceti letech od Felsensteinovy smrti odvážil narušit vžitou a zdánlivě neotřesitelnou představu slavného německého režiséra jako strůjce a realizátora tzv. realistického hudebního divadla. Východiskem bylo kritické přezkoumání veškeré dokumentace k Felsensteinovu životu a dílu, která se v minulosti nejednou stala předmětem ideologicky motivovaných zásahů, vedoucích k mylným interpretacím odkazu Waltera Felsensteina; Kehrmann mj. vydatně cituje z režisérovy korespondence s rodinnými př́ślušníky, zejména pak s jeho ženou Ellen Neumannovou (adresátem dopisů z dvacátých až čtyřicátých let byla v naprosté většině právě Neumannová).

Kniha je založena na důkladném heuristickém výzkumu a prezentuje autorovu schopnost invenčně interpretovat vytěžené poznatky. Odbornému čtenáři se tak dostává dosud nejobsáhlejšího výkladu felsensteinovské problematiky, v němž se režisérova osobní životní historie propojuje s profesním vývojem na pozadí převratných dějinných událostí a politicko-společenských změn v Německu první poloviny 20. století. Je pozoruhodné, že stěžejní závěry Kehrmann vyvodil ze studia málo reflektovaného předválečného období Waltera Felsensteina, v němž autor spatřuje četné paralely s etapou po druhé světové válce a s působením v čele Komické opery (Komische Oper). Ani založení Komické opery nebylo podle Kehrmanna ničím jiným než dovršením uměleckých záměrů a jejich institucionálních realizací, myšlenkových konceptů a reformních snah z předchozí éry Felsensteinovy divadelní činnosti.

Př́tomná studie si neklade za cíl pouhou sumarizaci základních, jakkoli převratných tezí Kehrmannovy monografie. Pokus o revizi konceptu hudebního divadla, kterému byl vnucen okolnostmi doby přívlastek „realistický“, vybízí k dalšímu uvažování. Ohlas a recepce Felsensteinových operních režií v zahraničí, zejména pak v zemích tzv. východního bloku, by měly vést $\mathrm{k}$ přezkoumání situace $\mathrm{v}$ domácím kontextu. Předmětem našich úvah se tedy stane situace v Československu, resp. v českých operních divadlech. Záměrem je položit si otázku, jak byl Felsensteinův vklad do inscenování opery přijímán v českém prostředí a zda tu našel své stoupence.

\section{Walter Felsenstein - člověk a umělec uprostřed dějinných zvratů}

O Walteru Felsensteinovi existuje v češtině pouze jedna biografická práce, jejíz forma je spíše popularizační. Karel V. Burian, autor publikace Walter Felsenstein z roku 1979, se zjevně inspiroval u Siegfrieda Melchingera a jeho knihy Musiktheater (1961), v níž je

1 Publikace zaujala v mezinárodní anketě kritiků prestižního německého časopisu Opernwelt „Kniha roku“ 2015 druhé místo. 
Felsenstein veden jako spoluautor a která byla v roce 1964 přeložena do slovenštiny. ${ }^{2}$ V obou publikacích se životní data německého režiséra ztrácejí v množství autorských digresí a asociativních vstupů; vykladači Felsensteinova díla se navíc nedokázali vyhnout některým nepřesnostem či chybám kupř. v inscenačních údajích. Z toho důvodu jsme se rozhodly zrekapitulovat v úvodní kapitole nejdůležitější mezníky životního a uměleckého vývoje Waltera Felsensteina. Zároveň se na konci pokusíme o stručnou charakteristiku jeho koncepce hudebního divadla.

Walter Felsenstein se narodil 30. května 1901 ve Vídni jako syn vyššího úředníka. Po zániku monarchie se rodina v souvislosti s otcovým povýšením u rakouských státních drah přestěhovala do Villachu. Zhroucení monarchie interpretuje Kehrmann jako zásadní zvrat ve Felsensteinově dosavadním životě, nebot z hlediska jeho zájmu o umění jednoznačně přinesl odklon od naturalismu k expresionistickému stylu: „Zážitek monarchie a revoluce se stal živnou půdou jeho ústředního životního tématu, jímž byl radikální zlom mezi starým a novým.“ (KEHRMANN 2015: 163) Otec chtěl, aby syn vystudoval techniku na univerzitě v Grazu, mladého Felsensteina však více přitahovalo divadlo. V letech 1921-1923 se učil privátně herectví ve Vídni (učitelem mu byl herec Burgtheatru a profesor na Státní akademii hudby a dramatických umění Ernst Arndt). V metropoli rakouského státu měl možnost sledovat umělecké působení režisérů, jakými byli Max Reinhardt nebo Leopold Jessner. Z divadel, která navštěvoval, na něj obzvláštní dojem udělalo divadlo Raimund-Theater se zaměřením na expresionistický inscenační styl. Již ke konci studia vystoupil profesionálně v několika malých rolích, v nichž překvapoval výbušnou jevištní mluvou a dovedností ve střídání různých hlasových zabarvení. Prvními zastávkami v jeho herecké kariéře se stala města Lübeck a Mannheim. Ve Stadttheater Lübeck zastihl éru intendanta Georga Hartmanna, který v letech 1923-1925 dokázal dříve konvenční scénu proměnit v jedno z nejprogresivnějších divadel v Německu. Vedle expresionistických her jako Wedekindův Markýz von Keith (Der Marquis von Keith) nebo Kaiserovo drama Peklo, cesta, zem (Hölle, Weg, Erde) zde zazněly např. i opery Paula Hindemitha Vrah, naděje žen (Mörder, Hoffnung der Frauen) a Ericha Wolfganga Korngolda Mrtvé město (Die tote Stadt). Ani v Lübecku, ani v mannheimském Národním divadle (Nationaltheater) se však nedostal k větším rolím. Důležitým mezníkem v jeho kariéře se stalo až období let 1925-1927, nesoucí se ve znamení angažmá ve Spojených městských divadlech (Vereinigte Städtische Bühnen) slezských měst Bytom (Beuthen), Gliwice (Gleiwitz) a Zabrze (Hindenburg). V Bytomi se uplatnil nejen jako herec, ale poprvé též coby dramaturg a režisér (uvedl se i jako režisér oper Bohéma a Fidelio). Mimoto se seznámil s první manželkou Ellen Neumannovou, ${ }^{3}$ dcerou bohatého židovského právníka, která se jako studentka uměleckoprůmyslové školy

2 Melchinger věnoval výkladu Felsensteinova života a jeho divadelní tvorby pouhou třetinu textu a navíc jej ukončil rokem 1947. Za tímto pojednáním o životě jsou poté za sebou řazeny Felsensteinovy úvahy o hudebním divadle a rozhovory. Součástí jsou rovněž Melchingerovy stručné poznámky k vybraným inscenacím Komické opery, které ovšem mají charakter ryze subjektivní dojmologie. Publikaci zakončuje ukázka z režijní knihy k inscenaci Sen noci svatojánské od Benjamina Brittena a seznam jevištní tvorby Waltera Felsensteina v Komické opeře v Berlíně do roku 1961.

3 Manželi byli od roku 1928 a z jejich svazku vzešli dva synové - Jürgen a Peter. Již krátce po začátku války se však Felsenstein sblížil s Marií Westphal, se kterou se oženil roku 1946. 


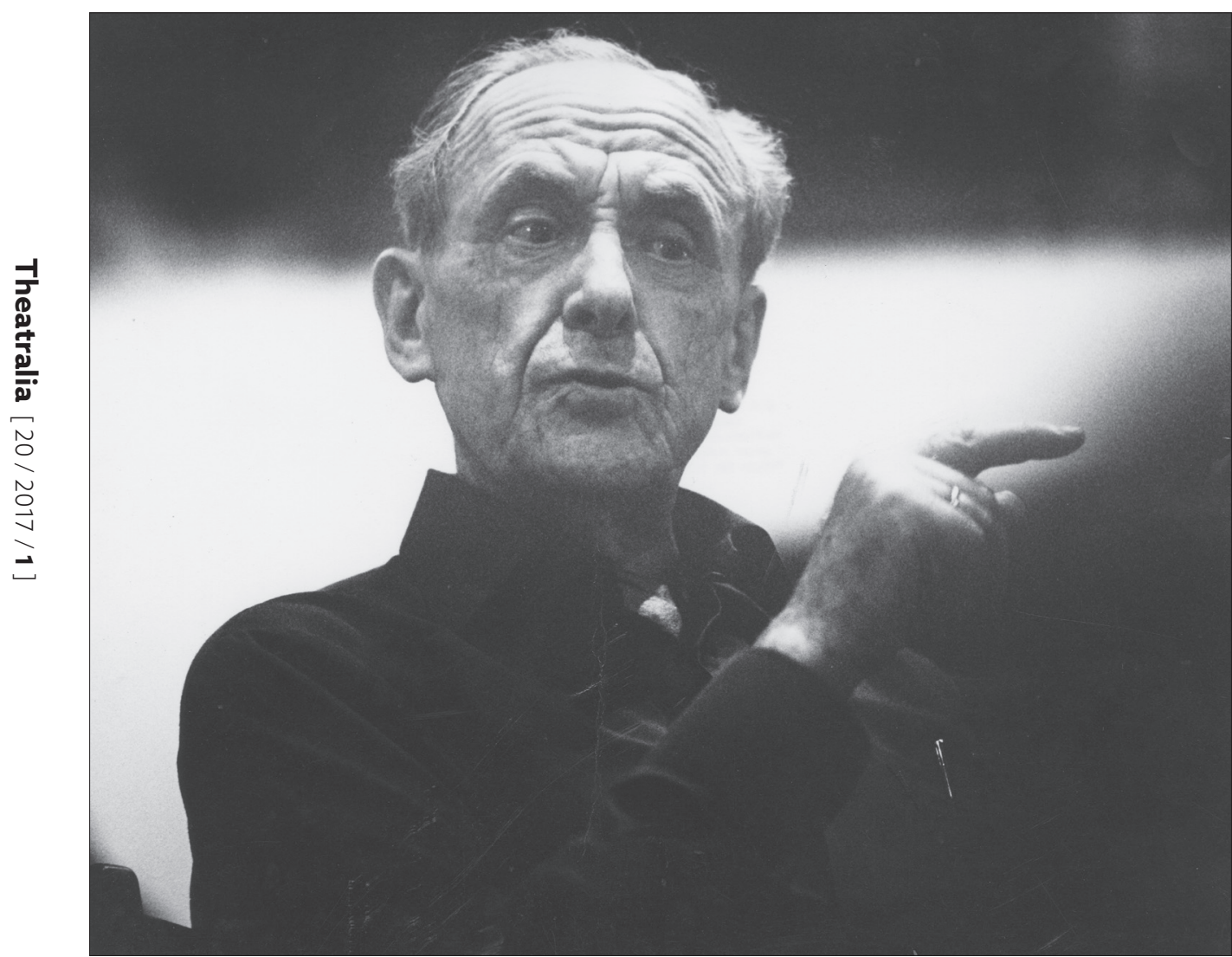

Obr. 1: Walter Felsenstein, 1973. (Akademie der Künste, Berlin, Walter-Felsenstein-Archiv, sign. 1695_08. Foto: Maria Steinfeldt).

v Berlíně stýkala i s představiteli divadelní avantgardy, zejména se aktivně zapojovala do činnosti divadelní dílny Bauhausu. V roce 1927 přijal Felsenstein místo režiséra pod intendantem Oskarem Wälterlinem ve Státním divadle v Basileji (Stadttheater Basel) $\mathrm{v}$ divadle, kde o tři roky dříve vzplanuly vášně kolem inscenace Wagnerova Ringu v režii švýcarského divadelního vizionáře Adolpha Appii. ${ }^{4} \mathrm{Na}$ této scéně, díky níž si rozšíŕil rozhled v oblasti současné divadelní tvorby také z hostování režisérů Jacquese Copeaua a Maxe Reinhardta, tanečníka Rudolfa Labana či souborů MCHAT a Grand Guignol, pak on sám v Appiově stylu vytvořil inscenaci Gluckova Orfea (1927) - bez dekorací, $\mathrm{s}$ účinkujícími v náznakových kostýmech a pohybujícími se na černém schodišti. Během dvou sezon strávených v Basileji vytvořil více než třicet činoherních a operních režií (režíroval např. Schillerovy Loupežniky a Valdštejnovu smrt, Strindbergovu Slečnu Julii, Thákurův Poštovni úřad, Hofmannsthalova Jedermanna nebo první díl Goethova Fausta,

4 Experiment musel být kvůli nepokojům, jež se přesunuly z divadelní budovy až na ulici, přerušen po inscenaci druhého dílu tetralogie, Valkýry. 
z oper Samsona a Dalilu od Saint-Saënse, Wagnerovy Mistry pěvce norimberské, Pucciniho Turandot, Straussova Růžového kavalíra aj.). Pro Felsensteinův inscenační rukopis bylo typické abstraktní výtvarné pojetí a důkladné propracování herecké složky (též u komparzu). Po tř́letém působení ve švýcarském Freiburgu (1929-1932), který on sám považoval za ztracenou „vartu“ (na obecenstvo působil „př́líš moderně“ inscenacemi Hindemithova Cardillaca, Bergova Vojcka a Straussovy Elektry), přešel roku 1932 do operního domu v Kolíně nad Rýnem. Zde už se koncentroval jen na hudební divadlo. Jako vrchní režisér frankfurtské opery (1934-1936) opřel svou režijní tvorbu o expresionistické výtvarníky Caspara Nehera a Ludwiga Sieverta. A co je rovněž důležité: působení ve Frankfurtu bylo spjato s Felsensteinovými prvními pokusy o inscenační reformu opery, podobajícími se jeho pozdějšímu počínání v Komické opeře (navrhoval „zeštíhlení“ repertoáru, pořizování speciální výpravy pro každou jednotlivou inscenaci namísto tehdy obvyklých dekorací z divadelního fundusu, rušení záskoků, průběžné přezkušování dříve nastudovaných inscenací, aby se udržela jejich vysoká umělecká kvalita apod.). Nástup Hitlera k moci, jenž ho zastihl v kolínském divadle, měl pro Felsensteina a jeho rodinu neblahé důsledky. Jako režiséra jej roku 1936 vyloučili z komory divadelníků a byl mu vydán zákaz účinkování a angažmá na německých scénách. Úspěšné operetní inscenace v privátním berlínském Admiralspalast mu stěží mohly zachránit existenci. Ve finančně neutěšené situaci sestavoval plány na založení operního studia v Salzburgu, jehož organizační struktura a umělecké zásady anticipovaly provoz později založené Komické opery. ${ }^{5}$ Po anšlusu Rakouska Felsenstein zkusil štěstí v neutrálním Švýcarsku a získal v curyšském Městském divadle pozici vrchního režiséra operety a opery. ${ }^{6}$ Krátce po premiéře Millöckerovy operety Gasparone v listopadu 1938, která se navzdory Felsensteinově nespokojenosti s úrovní uměleckého ansámblu setkala se senzačním úspěchem, zasáhla do jeho života v souvislosti s vývojem událostí v nacistickém Německu další tragédie - vyvlastnění manželčiny rodiny. Otec i matka Ellen Neumannové spáchali o pár let později sebevraždu, aby nebyli donuceni k deportaci (KEHRMANN 2015: 79). Sám Felsenstein byl na počátku roku 1939 na přímluvu vynikajícího herce a intendanta berlínského Schillerova divadla Heinricha Georga znovu přijat do divadelní komory. V letech 1940-1944 kromě angažmá ve jmenovaném divadle, kde inscenoval pouze činohru (zpočátku paralelně působil v Curychu), pohostinsky režíroval i v několika dalších německých divadlech (Cáchy, Düsseldorf, Štrasburk, Metz). Zapojil se také do Salcburského festivalu (Salzburger Festspiele).

Postoj a činy Waltera Felsensteina během trvání Třetí říše představují jednu z nejcitlivějších otázek, které se kolem osobnosti slavného režiséra vynořují. Není divu, že této rozporuplné etapě ve Felsensteinově životě věnoval Kehrmann zvýšenou pozornost ve snaze uvést věci na pravou míru. V minulých dobách, kdy byl Felsenstein považován za prominentního umělce a ikonu NDR, bylo pochopitelně v zájmu kulturtrégrů i odborných vykladačů jeho díla udržovat obraz režisérovy politické bezúhonnosti. Z toho

5 Kehrmann podotýká, že kdyby tuto školu tehdy založil - at’ v Rakousku, v Latinské Americe či Londýně, jak plánoval, - Komická opera už by neměla proč vzniknout. Srov. (KEHRMANN 2015: 37).

6 Ženě Ellen poručil, aby i s dětmi dočasně zůstala v Berlíně. V Německu neměl vzniknout dojem, že emigroval, aby kvưli tomu nedošlo ke zmaření dalších případných nabídek. Srov. (KEHRMANN 2015: 614). 
důvodu také v nejznámější edici Felsensteinových textů Schriften zum Musiktheater (FELSENSTEIN 1976) redaktor Stephan Stompor důkladně revidoval - škrtal či bez jakýchkoli skrupulí na řadě míst nově přepisoval - pasáže, které by mohly autora politicky diskreditovat, čímž se ovšem publikace stala bezcennou pro jakýkoli seriózní výzkum. ${ }^{7}$

V souvislosti s pozdějšími snahami převracet závěry z komunistické éry by bylo možné očekávat, že Kehrmann bude chtít na základě jakéhokoli vystopovaného náznaku Felsensteinovy př́ípadné loajality k nacistickému režimu prokázat režisérovo selhání tváří v tvář dobové realitě. Nic takového se však neděje: autor uvážlivě, věcně a s badatelskou poctivostí předestírá archivní dokumenty, které se vážou k Felsensteinovu veřejnému působení v letech 1933 až 1945, aby si čtenář sám mohl ověřit, že Felsenstein nebyl příznivcem národního socialismu. V některých krocích tohoto režiséra však bylo přinejmenším možné spatřit známky dobového oportunismu: veden ctižádostí udržet si pracně budovanou profesní pozici se dokázal obratně přizpůsobit novým provozním podmínkám na tehdejších německých scénách. Po neúspěšných pokusech o emigraci pro sebe neviděl jinou možnost, než zaujmout postoj pasivního odporu (KEHRMANN 2015: 91 a dále). Do roku 1935 publikoval několik článků, v nichž z čistě pragmatických důvodů užívá národněsocialistickou rétoriku; nikdy se však neúčastnil žádných veřejných akcí a manifestací na podporu tehdejšího režimu. Morálně sporných je pár jeho inscenací nacistických agitek v Schillerově divadle (kupř. hry Plukovnik Michael Maxe Geisenheynera nebo Rheinsberg Friedricha Forstera) - z dochované korespondence je přitom více než zjevné, s jakým odporem je jako režisér přijímal. ${ }^{8} \mathrm{Na}$ druhé straně zůstává naprosto nepochopitelné, proč svou ohroženou židovskou manželku i se syny během války znovu přestěhoval do Říše. ${ }^{9}$ Kehrmann se zdržuje jakýchkoli odsudků a kritických komentářů, poskytuje pouze prameny, jež svědčí o Felsensteinovu necitlivém chování k vlastní ženě v pro ni nesnadných chvílích po tragickém odchodu rodičů. Tvrdost a neústupnost v situacích, kdy šlo o profesní zájmy, byly zjevně jedním z charakteristických rysů jeho povahy a chování. ${ }^{10}$

Od počátku třicátých let, kdy se Felsensteinovi v hlavě rodila koncepce hudebního divadla, bylo tomuto režiséru zřejmé, že své umělecké plány bude moci plně realizovat jen ve vlastním divadle. Situace pro založení takové scény nazrála dva roky po válce. Operetě a varietním programům určený Metropol-Theater v Berlíně však Felsenstein převzal jen z nedostatku atraktivnějších příležitostí. Dostal k dispozici válkou zničenou budovy v architektonickém stylu dvojice stavitelo̊ Fellnera a Helmera, kterou bylo

7 Př́kladem může být redaktorský zásah do Felsensteinova článku z roku 1933 o Verdiho Trubadúrovi (inscenoval jej v Kolíně). Felsenstein užil formulace jako „nové Německo“ či „opravdové chápání národní pospolitosti“, jejichž zveřejnění nebylo v zájmu vydavatelo̊, a proto byly inkriminované pasáže bez jakýchkoli redakčních poznámek vyškrtnuty. Srov. (FELSENSTEIN 1976: 225-228). Citace z originálního Felsensteinova textu viz (KEHRMANN 2015: 94).

8 Srov. (KEHRMANN 2015: 721-734).

$9 \quad$ Ukrývali se v letním domku Felsensteinovy rodiny ze strany matky poblíž Melku v Dolním Rakousku.

10 Slova, která Ellen adresovala svému manželovi roku 1948, když už byli rozvedeni, vystihují, jak asi probíhal její život s člověkem plně oddaným uměleckému poslání: „Mám stále více dojem, že lidi tě zajímají, jen pokud je potřebuješ pro své režijní plány. [...] Přála bych si, abys byl jako člověk tak velký, jako jsi umělec.“ Cit. dle (KEHRMANN 2015: 968). 
třeba od základi̊ přebudovat. Licenci vystavenou na divadlo provozující operetu převzal z rukou zřizovatele majora Alexandra Dymšice, jenž byl vedoucím kulturního odboru Sovětské vojenské správy. Felsenstein se zavázal, že repertoár založí na „uměleckých“ operetách a komických operách, čímž legitimizoval přejmenování na Komickou operu (KEHRMANN 2015: 949). Nová scéna byla slavnostně otevřena 23. 12. 1947 představením Straussovy operety Netopýr; koncepci Felsenstein do posledního detailu převzal ze své dřívější inscenace z roku 1935 v berlínském Admiralspalastu (při premiéře si toho povšimli i někteří recenzenti) (KEHRMANN 2015: 962). Na konci první zkrácené sezony uvedl ještě Orffovu aktovku Chytračka (inscenaci si prý velmi oblíbil Bertolt Brecht) (KEHRMANN 2015: 971). V další sezoně 1948/49 pak následovaly tituly Orfeus v podsvětí, Carmen, Cikánský baron a Cokoli chcete (opera Was ihr wollt od Arthura Kusterera). Repertoár byl méně početný (a to i poté, co začali v padesátých letech samostatně režírovat Götz Friedrich, Joachim Herz a Heinz Rückert). O to větší důraz měl být položen na důkladné nastudování inscenací. Obvyklá byla tříměsíční doba zkoušení za Felsensteinovy permanentní přítomnosti. ${ }^{11}$ Na sklonku roku 1949 paralelně s Figarovou svatbou (1950) zkoušel lehkou operetu Carla Zellera Ptáčnik (1949), která se stala jedním z nejoblíbenějších inscenačních titulů scény. Nastudování Prodané nevěsty (1950) s Anny Schlemmovou a Rudolfem Schockem ${ }^{12}$ bylo doprovázeno značnými problémy, které vyvstaly zejména kolem překladu libreta do němčiny (Max Kalbeck). Felsenstein jej shledal jako nevhodný, kvůli čemuž dokonce na několik týdnů přerušil zkoušení. Poté, co si nechal pořídit Ottokarem Bischitzkým ${ }^{13}$ doslovný německý překlad, vytvořil svou vlastní verzi libreta. Premiéra byla všeobecně přijata s nadšením a Felsenstein za inscenaci převzal spolu s některými dalšími účinkujícími Národní cenu II. třídy za umění a literaturu. Po Offenbachově Pařižském životě a Weberově Čarostřelci (obě 1951) následovaly inscenace Verdiho Falstaffa a značně zrevidovaného Lortzingova Cara a tesaře (obě 1952). ${ }^{14}$

Od počátku padesátých let byl Felsenstein vystaven permanentnímu tlaku kulturní politiky NDR. Musel průběžně čelit neblahým důsledkům organizačních opatření, nebot’ velká část uměleckého a technického personálu pocházela ze západního Německa

11 Zatímco v sezoně 1948/49 režíroval Felsenstein v Komické opeře čtyři tituly, v sezoně 1949/50 už jen tituly dva, 1950/51 počet jím nastudovaných inscenací stoupl na číslo tři, avšak v následujících sezonách až do 1953/54 vytvořil pouze po jedné operní inscenaci. V sezoně 1954/55 byl podepsán pod dvěma operními režiemi a v období 1955/56 zase jen pod jednou. Následně pro Komickou operu nerežíroval nic, v další sezoně opět pouze jediný titul. Rovněž v sezoně 1958/59 následovala pauza, avšak poté (1959/60 a 1960/61) režíroval pokaždé dvakrát. Od té doby do konce šedesátých let v Komické opeře nastudoval pouze tři hudebně dramatická díla (pět inscenací nastudoval v jiných německých operních divadlech) a v letech sedmdesátých (do konce života) pak opery čtyři, přičemž se věnoval i činoherní režii v Burgtheatru (dvě inscenace) a v mnichovském Residenz-Theater (jedna inscenace).

12 Původní obsazení bylo Elfride Trötschel v roli Mařenky a Heinz Sauerbaum jako Jeník.

13 Ottokar Bischitzky (1924-1992) byl potomkem pražské německo-židovské rodiny, která se usídlila v Berlíně, v roce 1933 prchla před Hitlerem zpět do Československa a po válce se vrátila zpět do Německa. Bischitzky vystudoval slavistiku na Humboldtově univerzitě a později se stal kulturním redaktorem východoněmeckého rozhlasu.

14 Kvůli nežádoucím politickým konotacím syžetu Lortzingovy komické opery byl Felsenstein Státní radou pro umělecké záležitosti varován před jakýmikoli extempore účinkujících (KEHRMANN 2015: 1015). 
(sám Felsenstein se přestěhoval do východní části Berlína až roku 1966). Po vzniku berlínské zdi v srpnu 1961 díky svému prominentnímu postavení docílil, že ztráty západoněmeckých členů souboru byly mnohem nižší, než k jakým docházelo v jiných divadlech. Ani on se však nevyhnul razantnímu poklesu návštěvnosti a řadu titulů musel přestudovat s nově angažovanými umělci z východního bloku.

Jedním z milníků Felsensteinovy inscenační tvorby byla Kouzelná flétna (1954; př́iprava inscenace se vlekla už od podzimu 1952). Význačný kritik Ernst Kraus označil inscenaci jako do té doby největší výplod Felsensteinovy scénické fantazie, v němž režisér vytvořil „svou vlastní realitu“ (citováno dle KEHRMANN 2015: 1029). Jednalo se současně o první pokus interpretovat toto Mozartovo dílo v duchu aktuálně zaměřeného politického divadla (KEHRMANN 2015: 1026). ${ }^{15}$ Rovněž ve Straussově výrazně přepracované Noci v Benátkách, jejíž premiéra se uskutečnila téhož roku, se Felsenstein soustředil na satirické ztvárnění senátorů a jejich dvojí morálky; upravoval text tak, aby jejich řeč přiblíżil agresivnímu duktu kulturních ideologů východoněmeckého státu, s nimiž vedl $\mathrm{v}$ té době nekončící boj (KEHRMANN 2015: 1034-1035). Po premiéře Straussovy Mlčenlivé ženy, která se dostala na repertoár na samotném konci roku 1954, nastal ve Felsensteinově režijní tvorbě dočasný útlum. Pod inscenacemi Komické opery z období roku 1955 až května 1956 Albert Herring, Lazebnik bagdádský (Cornelius), Náměstićcko (Wolf-Ferrari), Čarostřelec, Manon Lescaut a Síla osudu byli podepsáni bud' Heinz Rückert nebo Joachim Herz. V květnu 1956 Komická opera poprvé hostovala na Pražském jaru a krátce poté se Felsenstein berlínskému publiku představil s Janáčkovou operou Př́hody lišky Bystroušky (uvedl ji pod zkráceným názvem Liška Bystrouš$k a) .{ }^{16}$ Zdařilé, rozporuplně přijaté interpretaci tohoto opusu s Irmgard Arnoldovou a Rudolfem Asmusem v titulních rolích se dostalo nebývalého mezinárodního ohlasu, což se dosud nestalo u žádné z předešlých inscenací Lišky. ${ }^{17} \mathrm{~S}$ další premiérou přišel Felsenstein až v lednu 1958. Inscenačnímu procesu Hoffmannových povídek předcházela - nejinak, než tomu bylo u řady předchozích děl - razantní úprava libreta. Hudební čísla pospojoval ve stylu opéry comique mluvenými dialogy namísto recitativů, dokomponovaných po skladatelově smrti Ernestem Guiraudem. Felsenstein kromě toho vyškrtl téměř polovinu z celkem 44 čísel, přičemž zbývající čísla ještě dále upravoval. (Někteří kritikové označovali jeho zásah jako „zmrzačeni“ Offenbachovy partitury). ${ }^{18} \mathrm{~V}$ ř́jjnu 1959 uvedl Othella (o deset let později vznikl i film ve studiu DEFA). K předposlední Verdiho opeře choval zvláštní respekt; považoval ji za vrcholné naplnění požadavků

15 Kehrmann nahlíží Felsensteinovu Kouzelnou flétnu ve světle největší události doby, během níž se rodila koncepce inscenace, totiž úmrtí J. V. Stalina. Srov. kap. 6.3 „Projektionen eines Idealstaates: Sarastro und Stalin“ in (KEHRMANN 2015: 1025-1040).

16 Felsensteinovo nadšení pro Janáčka se datovalo už od třicátých let, zásadní impuls k režii některé z Janáčkových oper vzešel ale mnohem později od Václava Neumanna, který debutoval jako dirigent Komické opery roku 1954. Neumann navrhoval Kátu Kabanovou, Felsenstein se však nakonec rozhodl pro Lišku Bystroušku. $\mathrm{V}$ době, kdy Komické opeře povážlivě ubývali diváci, potřeboval do repertoáru operu méně závažnějšího charakteru (KEHRMANN 2015: 1046).

17 Inscenace se v Komické opeře uváděla do roku 1964 a dosáhla přes dvě stovky repríz. Divadlo s ní hostovalo v různých evropských městech a režisér připravil i remake pro milánskou Scalu (1958). 
hudebního divadla. Jeho interpretace spočívala v akcentování společenské determinace Othellovy žárlivosti. V postavě Jaga rozvinul hlubokou psychologickou studii člověka zmítaného komplexem méněcennosti. ${ }^{19} \mathrm{~K}$ nejzapamatovatelnějším částem inscenace patřil výjev bouře z úvodu 1. dějství, který bývá podnes citován jako vzorová ukázka Felsensteinovy schopnosti dosáhnout dokonalé jednoty hudby, dramatu a scény. ${ }^{20}$ Další premiéra v režii Waltera Felsensteina, Lazebnik sevillský Giovanniho Paisiella, byla výsledkem koprodukce Komické opery a festivalu ve Schwetzingenu. Do roku 1962, kdy bylo divadlo na několik let uzavřeno za účelem rekonstrukce, nastudoval v Komické opeře Traviatu (pod její režií byl v témže roce podepsán i v hamburské Státní opeře), Brittenův Sen noci svatojánské a Offenbachovu operetu Rytiř Modrovous. Premiérou Dona Giovanniho na sklonku roku 1966 došlo k znovuotevření scény. Do konce šedesátých let následovala už jen jediná inscenace v režii Waltera Felsensteina - Prokofjevova Láska ke třem pomerančum; Felsenstein více režíroval v jiných německých divadlech (v roce 1969 nastudoval v moskevském Hudebním divadle Stanislavského a Němiroviče-Dančenka Carmen). Americký muzikál Šumař na střěse (1971), Carmen (1972), Kodályho Háry János (1973) a Figarova svatba (1975) byly posledními tituly, pod nimiž byl v Komické opeře podepsán jako režisér. Jeho vůbec poslední inscenací byl Goethův Torquato Tasso, jehož premiéra se uskutečnila v červnu 1975 ve vídeňském Burgtheatru. Zemřel 8. ř́jna 1975. $\mathrm{V}$ rámci pietního aktu $\mathrm{v}$ Komické opeře, který proběhl o týden později a zúčastnili se ho nejdůležitější zástupci politického a kulturního života NDR, pronesl jeden ze zásadních projevů pěvecký matador ansámblu Rudolf Asmus a mimo jiné zde zazněly i hudební ukázky z Janáčkových Př́hod lišky Bystroušky.

$$
* * *
$$

Pojem hudebni divadlo je u Felsensteina potřeba chápat jako výtvor hudebně inscenačního procesu. Základem se může stát pouze takové skladatelské dílo, v němž je dosaženo dokonalé syntézy hudby a dramatu. Felsenstein hovořil o tom, že jen v hodnotných operách souhlasí libreto s hudbou od prvního taktu. Kdo umí číst v partituře, najde zde vše, co potřebuje k jejímu „pravdivému“ divadelnímu vyjádření (FELSENSTEIN 1956: 602). Taková díla pro sebe nacházel v mozartovské opeře a v hudebně dramatické tvorbě 19. století (významné zastoupení měly zpěvohry a klasické operety). Dủležitým kritériem výběru bylo i určité literární zázemí díla stejně jako jeho vstřícnost k plastickému modelování aktérů děje. Málokterou operu či operetu inscenoval v originální podobě, uvedení vždy předcházela menší či rozsáhlejší dramaturgická úprava.

Svým konceptem hudebního divadla Felsenstein navazoval na wagnerovské pojetí hudebního dramatu jako dokonalé jednoty všech uměleckých složek. Syntézou děje, hudby, výtvarného a hereckého vyjádření se stavěl proti konvenci tzv. pěvecké opery.

19 O dramaturgicko-inscenačním výkladu Verdiho opery v inscenaci z roku 1959 se Felsenstein rozhovořil v interview s Dieterem Kranzem, který je v podobě audionahrávky dostupný na DVD Walter Felsenstein Edition, Giuseppe Verdi: Othello (Arthaus Musik GmbH, 2009).

20 Za účelem davových scén $\mathrm{v}$ této opeře bylo nutno rozšíriit prostor jeviště o proscénium, na které umístil co nejblíže obecenstvu v závěru umírajícího Othella (FELSENSTEIN a MELCHINGER 1964: 40). 
O ní hovořil jako o „kostýmovaném koncertu“, kdy se absolutní hodnotou stává pouze předvedení zpěvákovy virtuozity. Aby nedošlo k mýlce: rovněž Felsenstein stavěl do středu hudebně divadelní reality zpěváka, šlo mu však o nový typ pěveckého interpreta, jenž svůj krásný hlas propůjčuje pravdivému a přesvědčivému ztvárnění dramatické situace a jednající postavy (FELSENSTEIN, FRIEDRICH a HERZ 1970: 44). ${ }^{21}$ Kardinální úkol hudebního divadla spatřoval Felsenstein ve vytvoření bezvýhradně hodnověrné divadelní reality na základě hudby a zpěvu. O úloze zpěváka říká: „[j]eho studium - a to nejen vlastního pěveckého partu, nýbrž celé orchestrální partitury - musí stejně tak jako herecký výraz dosáhnout takové dokonalosti, že divák si jej uvědomuje jako dramatického a uměleckého tvůrce a nabude dojmu, že je to on, z něhož vzchází veškerá hudba, přičemž orchestr ho jenom doprovází." (FELSENSTEIN, FRIEDRICH a HERZ 1970: 45)

Felsenstein nevnímal zpěváka jako pouhého interpreta role, $v$ jeho pojetí byl takřka tvůrcem díla na jevišti. Na otázku „proč člověk zpívá“, kterou si Felsenstein v souvislosti se svými požadavky na operního zpěváka nejčastěji pokládal, odpovídal, že nikoli snad proto, aby ukázal svůj krásný hlas a protože se zpívat naučil, nýbrž proto, že se v rámci určité dramatické situace nemůže vyjádřit jinak: „Musí emocionálně učinit věrohodným, že mu k vyjádření nebyly dány jiné prostř̌edky než zpěv." (FELSENSTEIN, FRIEDRICH a HERZ 1970: 44) ${ }^{22}$ Vše, tedy i zpěv, musí předestřít jako nezbytný projev svého vnitřního stavu, jako zákonitý výraz vlastního chtění. „Nesmíme mít ani na okamžik pocit, že by se mohl projevit i jinak, jinými slovy a tóny." (FELSENSTEIN, FRIEDRICH a HERZ 1970: 68$)^{23}$

V rámci nejrůznějších diskusí o opeře jako o menšinovém žánru, v němž nachází zalíbení nepočetná skupina publika, Felsenstein vyjadřoval přesvědčení, že zájem o operu stoupne jedině tehdy, když divák dokonale porozumí tomu, co zpěvák zpívá - a to nejen ve smyslu zřetelnosti deklamace, která by měla být samožrejmostí. To, co měl Felsenstein na mysli, bylo porozumění dramatické situaci. Její srozumitelnost je podle něj jen a jen v moci zpěváka, jeho hlasových a hereckých prostředků. Pokud se divák ptá, proč zpěvák zpívá či jedná tak či onak, dělá něco špatně, tvrdíval Felsenstein (FELSENSTEIN a MELCHINGER 1964: 72).

Jestliže zpěváku byl přisouzen tvůrčí primariát, zbývá odpovědět na otázku, jaké postavení zastával ve Felsensteinově koncepci hudebního divadla dirigent a režisér. Dirigent se má plně podřídit realizaci hudebního divadla, prožívat dramatičnost příběhu spolu se zpěvákem a svým dílem usilovat o to, aby ho co nejlépe realizoval. U režiséra Felsenstein zdůrazňoval jednoznačně služebnou roli: režisér může pouze podnítit a s pomocí uměleckých prostředků inscenace podpořit hudebně divadelní zážitek. Jeho bezvýhradnými nositeli jsou však hudbu vytváŕející a hrající lidé („musizierende und darstellende Menschen") (FELSENSTEIN, FRIEDRICH a HERZ 1970: 44), ${ }^{24}$ jimž je režisér pouze

21 V níže uvedených odkazech pod čarou odkazujeme ke konkrétním článkům, z nichž je citováno. Uvádíme jméno autora a název článek. FELSENSTEIN, Walter. Die Operninszenierung.

22 FELSENSTEIN, Walter. Die Operninszenierung.

23 HERZ, Joachim. Von der Realität des singenden Menschen.

24 FELSENSTEIN, Walter. Die Operninszenierung. 
oporou. Je tím, kdo řekne, zdali je vnitřně pravdivý pocit zpěváka zřejmý a čitelný také publiku (FELSENSTEIN, FRIEDRICH a HERZ 1970: 70). ${ }^{25}$ Technické a estetické inscenační otázky mají podle Felsensteina celkově méně podstatný význam. („Režisér se nikdy nesmí omezit na opticko-prostorové a choreografické provedení a není mu dovoleno použít zpěváků jako pohyblivých figur, místo aby je pobídl k tvưrčímu dokreslení a dobásnění díla.“ [FELSENSTEIN 1956: 602]) Jakkoli se tedy sám Felsenstein v rámci inscenačního procesu režijně projevoval výrazným způsobem a často přinášel osobitý dramaturgický výklad operního díla, jeho uvažování o tzv. režijním divadle bylo v zásadě negativní. Hudební divadlo nelze chápat jako „intronizaci režisérské hvězdy“ (FELSENSTEIN, FRIEDRICH a HERZ 1970: 70). ${ }^{26}$ Tím, kdo v hudebním divadle vládne, není ani dirigent, ani režisér, je jím „přemýšlivý a do své postavy se proměňující zpěvák“ (FELSENSTEIN, FRIEDRICH a HERZ 1970: 70). ${ }^{27}$

\section{„Realistické" hudební divadlo jako mýtus?}

V úvodu své práce Kehrmann zdůrazňuje, že kniha vznikla s cílem zbavit Waltera Felsensteina klišé „realisty“ a zproblematizovat tradiční představu o něm jako o ikoně divadelního umění v éře DDR (KEHRMANN 2015: 17).

Legenda o Felsensteinově „realistickém“ hudebním divadle se měla zrodit po roce 1950 a v německém kontextu zakořenila tak pevně, že se podle Kehrmanna v odborné literatuře dodnes stěží najde publikace nebo článek, kde by tohoto epitetonu u režisérova jména nebylo užito. (Tutéž klasifikaci pak přejímají i zahraniční práce.)

Felsenstein nebyl tím, kdo by do operního divadla uvedl označení realistisches $M u$ siktheater. Ve spojení s pojmem hudební divadlo mu bylo bližší adjektivum „reálné“ (reales Musiktheater) (KEHRMANN 2015: 24). Měl na mysli operní divadlo, založené na umění zpívajících lidí, kteří jsou schopni v rámci jevištní skutečnosti vzbudit dojem obsahové pravdivosti a přesvědčivosti. Proto pojmy Glaubwürdigkeit (věrohodnost) nebo Wahrheit (pravdivost), kterými tak často označoval výsledek, jehož musí zpěvák s pomocí dalších složek operní inscenace dosáhnout, nelze chápat ve smyslu realismu jakožto uměleckého stylu, snažícího se na scéně stvořit co nejvěrnější nápodobu skutečnosti (KEHRMANN 2015: 66). Přesně proti tomuto vnímání pojmu realismus - nepochybně i z důvodů jeho přivlastnění ideology socialistického umění - se Felsenstein kriticky vymezoval.

Z jeho úvah o opeře vyplývá, že jej debaty o realismu vlastně př́liš nezajímaly. Joachim Herz se u př́ležitosti sympozia věnovaného Felsensteinovi a konaného v listopadu 2006 v berlínské Komické opeře nechal slyšet, že pojem „realistisches Musiktheater“ od režiséra, se kterým spolupracoval více než dvacet let, ani jednou neslyšel (HINTZE,

25 HERZ, Joachim. Von der Realität des singenden Menschen.

26 Ibid.

27 Ibid. 
RISI a SOLLICH 2008: 49). ${ }^{28}$ Je tedy na místě otázka, odkud se vžité označení Felsensteinovy metody hudebního divadla jako „realistické“ vlastně vzalo. Podle Kehrmanna šlo o pouhou nálepku východoněmeckých stranických funkcionářů, která vznikla v rámci transformace kultury v nově vzniklém státě pod egidou socialistického realismu (KEHRMANN 2015: 64-65).

Vůbec prvním, kdo měl pojem realismus v souvislosti s Felsensteinovou režijní tvorbou použít, byl sám generální tajemník $\mathrm{SED}^{29}$ a čelný představitel východoněmeckého státu Walter Ulbricht. V gratulaci k režisérovým padesátinám, jako výraz obdivu k jeho dílu, v květnu roku 1951 napsal, že Felsensteinovo vpravdě „realistické umění má působivý účinek na pracující lid“ (citováno dle KEHRMANN 2015: 65). ${ }^{30}$ Jak však Kehrmann opakovaně dokládá na základě nejrůznějších Felsensteinových ústních i písemných prohlášení, režisér záhy dokázal jemu vnucené značky pragmaticky využít: když to situace vyžadovala, nejčastěji ve spojení s ekonomickými obtížemi Komické opery, vzal termín „realistické hudební divadlo“ do úst i on sám, vědom si jeho politické konjunkturálnosti. Už v prosinci 1951 hovořil před členy berlínské Volksbühne o tom, že jeho divadlo vzniklo proto, aby bylo možné pokračovat v dosavadním úsilí a dále jej rozvíjet o „realistické hudební divadlo“ (za předchůdce označil Richarda Wagnera, Alberta Carrého a Hanse Gregora) (KEHRMANN 2015: 66). Rétorika kulturtrégrů se mu poté vyplatila vždy, když potřeboval účinnou zbraň k udržení Komické opery, která požívala status „výstavní skříně východoněmecké kultury“. Tuto strategii užíval zvláště po vzniku berlínské zdi, kdy byla existence Komické opery s půldruhou stovkou zaměstnanců ze západního Berlína a Německa nanejvýše v ohrožení. Felsenstein dosáhl díky schopnosti vyjednávat s nejvyššími představiteli státu nemožné: zatímco jiná divadla ve východním Berlíně musela znovubudovat soubory bez účasti umělců ze západu, do Komické opery denně dojížděla řada pracovníků ze západní části Berlína a větší část platu dostávala v západoněmeckých markách. Rakušan Felsenstein se zkrátka vždycky dokázal s vrchností NDR nějak domluvit. A co Kehrmann považuje za příznačné: používal k tomu stejnou taktiku, po jaké sahal i v době nacistické diktatury. ${ }^{31}$

Felsenstein užití pojmu realismus od padesátých let až do smrti neúnavně proměňoval a relativizoval. „Realistický není precizním slovem. Bylo by lepší jednoduše říci: srozumitelný nebo nesrozumitelný“, vyjádřil se v rozhovoru pro BBC na počátku sedmdesátých let (citováno dle KEHRMANN 2015: 231). Každá doba si pod realistickým ztvárněním

28 HERZ, Joachim. „Einer von den kleinen Felsensteinen...“. Vom Erben, vom Weiterreichen und vom Vergessen.

29 Sjednocená socialistická strana Německa (Sozialistische Einheitspartei Deutschlands).

30 Felsenstein, zřejmě aby se vyhnul ideologické rétorice, použil v odpovědi Ulbrichtovi spojení „obnova hudebního divadla“, což definoval jako hlavní cíl svého uměleckého snažení (KEHRMANN 2015: 65).

31 V knize je např. ocitován Felsensteinův fiktivní dopis na obhajobu jeho vlastní inscenace Verdiho Trubadúra v kolínské opeře z října roku 1933 (byl otištěn v časopisu Die Tribüne). Felsenstein v něm mj. uvádí, že jedině opera může ve své smyslové totalitě napomoci uskutečnění národní pospolitosti („Volksgemeinschaft“) německého lidu. O sedmnáct let později, u prŕležitosti 70. narozenin J. V. Stalina, hovořil v podobném smyslu před souborem Komické opery, pouze korigoval nacionálněsocialistický výraz „Volksgemeinschaft“ a namísto něho použil formulaci Ganzheit des werktätigen Volkes („celistvost pracujícího lidu“). Srov. (KEHRMANN 2015: 493-494). 
představuje něco jiného, provždy platná definice realismu jako stylu tedy podle Felsensteina není možná: „O definici realismu jako stylu bychom se pokoušeli marně, protože těžko prověřit, kolik jsme toho dodnes převzali z naturalismu, expresionismu a jiných ismů." (FELSENSTEIN, FRIEDRICH a HERZ 1970: 33$)^{32}$

V jednom z klíčových projevů z raných padesátých let, jenž Felsenstein přednesl před reprezentací státu v Theater am Schiffbauerdamm u př́ležitosti oslav 85. výročí narození Maxima Gorkého, sarkasticky okomentoval stereotypní, vyprázdněné používání pojmu realismus se všemi jeho variantami: „Je podivuhodné, kolik lidí, kteří stojí na jevišti, a jak ještě více lidí, kteří na jevišti nikdy nestáli, si dnes o realistické jevištní tvorbě, o kritickém realismu a realismu socialistickém něco myslí a umějí o tom mluvit. Alarmující je ale i to, když berou do úst závazná a důležitá tvrzení, aniž by tušili, k jakému účelu tyto poznatky a tvrzení vznikly, a uměli je použít, čímž jen páchají škodu, nebot šíríi nesmyslné bláboly.“ (FELSENSTEIN, FRIEDRICH a HERZ 1970: 35)

V roce 1971, u př́ležitosti svých sedmdesátin, si v televizním portrétu, natočeném známou dokumentaristkou Gittou Nickel, postěžoval, že pojem „realistické hudební divadlo“ byl postupem doby zneužit do takové míry, že je třeba se pokusit najít jiné označení pro to, oč se svým souborem Komické opery jako režisér usiloval a nadále usiluje (KEHRMANN 2015: 57).

V neustálém uvědomování si divadla jako umělé reality a přiznáváním „ireálné“ podstaty opery, vyplývající ze zpěvu jako vyjadřovacího prostředku, Felsenstein zdůrazňoval, že realismus nesmí být zaměňován s jakoukoli formou naturalismu. Proto ani rozlišování realismu a formalismu nemá pro uměleckou praxi prý žádnou platnost (KEHRMANN 2015: 57). „Označení realismus se vztahuje na obsah [...] lidského vyjádření, nikoli na styl. Tudíž i představení, jež je realizováno ve stylizované dekoraci, může být plně realistické." 33

Ve Felsensteinových nejrůznějších provoláních a vyjádřeních od dvacátých let až do konce jeho života můžeme nahlédnout kontinuitu myšlení o divadle a o opeře, spočívající v pojímání divadelního umění jako stylizované reality, jež umožňuje skutečnost zažívat jinak než v běžném životě. Opera díky zpěvu irealitu divadla ještě umocňuje. Zpěvu Felsenstein přisuzoval tutéž schopnost, jakou symbolisté viděli v hudbě: vyjádřit skryté významy, pocity a myšlenky, které slovem (a tudíž činohrou) nelze plně postihnout.

V dopisu Carlheinzu Hillekampsovi z 21. dubna 1938 osvětlil důvody, proč se vydal na dráhu opery poté, co řadu let režíroval činoherní inscenace:

[...] Začal jsem jako herec, stal jsem se po čtyřech letech režisérem (všech divadelních žánrů) a po dalších pěti letech jsem dal přednost opeře, nikoli snad proto, že by mi tento žánr mezi tehdejšími i dnešními formami přišel jako obzvlášt lákavý, nýbrž proto, že tváří v tvář hrozivě zploštělému a zvěcnělému vývoji divadla [má na mysli činohru - pozn. $H S$, ŠHK] na sebe

32 FELSENSTEIN, Walter. Rede zur Gorki-Feier 1953.

33 Slova pronesl v dokumentu Gitty Nickel nazvaném Walter Felsenstein (DDR, 1971). Cit. dle (KEHRMANN 2015: 231). 
hudební divadlo vezme úkol obhájit a vystupňovat v nejširším smyslu a silou své vyšší ireálnosti tvưrčí aktivity divadelního umění, které se setkává stále více s banální interpretací a výlučně reprodukční podstatou. (KEHRMANN 2015: 27)

Felsensteina na opeře evidentně zajímalo to, co postrádal v dobovém činoherním divadle - její vysoce antiiluzivní podstata. ${ }^{34}$

Roku 1971 se vyslovil, že nejdůležitějším a nejvlivnějším uměleckým směrem 20. století zůstává i nadále expresionistický styl: „to, co dnes nazýváme realistickým divadlem, žije podstatným dílem z expresionismu“ (FELSENSTEIN 1991: 82; citováno dle KEHRMANN 2015: 203). Nejvíce jej prý oslovili režiséři Alexandr Tairov5, Leopold Jessner, Jürgen Fehling ${ }^{36}$, Peter Brook ${ }^{37}$ a Giorgio Strehler. Jestliže u něj jmenovaní divadelníci měli takový ohlas, nabízí se samozřejmě otázka, jak se s poetikou těchto režisérů srovnává koncept divadla v duchu realistického stylu.

Kehrmann se oproti očekávání v knize přiliš nevěnuje souvislostem mezi Felsensteinovou metodou a systémem Stanislavského. Aniž by existovaly konkrétní důkazy, že byl Felsenstein s teorií Stanislavského blíže obeznámen a studoval jeho spisy, ${ }^{38} \mathrm{v}$ metodickém

34 V článku „Über das Pathos des Schauspielers“ (1931) se Felsenstein vyjádřil, že činoherní divadlo skomírá, protože z herectví se vytratil patos. Význam tohoto pojmu mu zřejmě splýval se stylizací, povýšením skutečnosti do vyšší, běžnou realitu přesahující roviny. Jestliže dříve prý dosahoval herec patosu takřka výhradně skrze deklamaci, v aktuální době - v důsledku celkově střízlivějšího způsobu divadelního ztvárnění - je nutné na diváka působit jinak, zejména prostřednictvím hercovy fyzické akce. Zdůrazňoval význam „mima, který dnešního diváka řečí, mimikou a gestem, vystupňovaným do podoby tance, zavede do říše umělecké, realitě vzdálené pravdy." Tento typ herce zřejmě neměl v jeho pojetí daleko k opernímu zpěvákovi. Srov. k tomu (KEHRMANN 2015: 471-474).

35 Vliv Tairova a obdiv k jeho divadelní tvorbě provázel Felsensteina až do konce života. V roce 1950 plánoval v Komické opeře uvést Lecocqovu operu buffu Giroflé-Girofla, kterou stavěl na vrchol Tairovovy inscenační tvorby, ale nakonec zůstalo pouze u dlouhého zkoušení; s výsledkem nebyl Felsenstein spokojen, a tudíž k premiéře nedošlo. Před válkou nazkoušel několik inscenací v přiznaném tairovovském stylu syntetického herectví s prvky akrobacie a tance. Z herců Komorního divadla jím nejvíce obdivovaný Vladimir Sokolov se podle Kehrmanna „obtiskl“ i do několika Felsensteinových poválečných inscenací, mj. ocitoval v roli Krále Bobècha (J. Offenbach: Rytîr Modrovous, 1963) Sokolovova směšného Dauphina z Tairovovy slavné inscenace Shawovy Svaté Jany (KEHRMANN 2015: 228).

36 Felsenstein se inspiroval estetikou „nekonečného“, prázdného a tmavého prostoru, jež byla považována za specialitu režiséra Jürgena Fehlinga, který působil v letech 1922-1944 s přestávkami v berlínském Státním divadle. Felsenstein byl s jeho inscenacemi dobře obeznámen, protože Fehlingovu tvorbu sledoval. Postupy tohoto režiséra uplatnil kupříkladu ve svých jevištních ztvárněních Čajkovského Pikové dámy či Ibsenova Johna Gabriela Borkmana (obě 1940). Ohlas na Fehlingovu poetiku lze najít ještě i v jeho poválečné tvorbě v Komické opeře. V duelu Hoffmanna a Schlemihla v Hoffmannových povídkách (1958) Felsenstein citoval souboj Dona Juana a Komtura z Fehlingovy inscenace Grabbovy hry Don Juan a Faust (1936), jenž se rovněž odehrával před bílou zdí, která ubíhá šikmo do hloubky scény. Svíčky, vykrajující postavy ze tmy, jež Fehling se zdarem využil kromě inscenace uvedené Grabbovy hry rovněž v Richardu III. (1936), zase včlenil Felsenstein se záměrem evokovat vnitřní stavy a myšlenkové pochody postav do concertata ve třetím aktu Verdiho Othella (1959). Další příklady srov. (KEHRMANN 2015: 715).

37 U Brooka obdivoval jeho teorii prázdného prostoru, s jehož praktickou podobou se mohl seznámit v únoru 1964 v rámci hostování Royal Shakespeare Company v západoberlínském Schillerově divadle (KEHRMANN 2015: 383).

38 Felsenstein ruštinu neovládal a oba díly knihy Práce herce na sobě samém vyšly v úplném německém překladu až na počátku 60. let. Relativně brzy však vyšly v němčině dvě práce zabývající se Stanislavského systémem i jeho operními režiemi (srov. ANTAROWA 1951 a KRISTI 1954). 
ohledu nesporně rozvíjel některé postupy, jež byly se Stanislavského pojetím herecké tvorby totožné. Bez toho, že by se ve svých pojednáních zaštitoval Stanislavského jménem, zdůrazňoval, že emocionalita zpěváka musí neustále korespondovat s vnitřním obsahem dané role. A dodával, že zpěvák musí do ztvárnění své postavy vložit vlastní přirozený výraz (s odkazem na Brechta tvrdil, že at již má herec emoce prožít, či zcizit, musí se vždy v tomto procesu emocionálně angažovat, být schopen patřičného citového „vzrušeni“) (FELSENSTEIN a MELCHINGER 1964: 60). S herci mluvil a usilovně s nimi pracoval na „podtextu“ postavy, její psychologické motivaci a historii. Zpěvák musel vědět o své postavě „vše“, jestliže chtěl dosáhnout plně věrohodného ztvárnění, a pohnutky jednání měly být zřejmé z každé scény stejně jako z celku díla. (V pracích o Felsenteinovi se často zmiňuje, kterak precizní režisér psal ke každému představení obšírné dopisy hlavním představitelům s detailním vysvětlením, jak si představuje ten či onen jejich výstup.) Studiu díla na scéně předcházela důkladná dramaturgická analýza; není pochyb o tom, že hudební divadlo se v pojetí Waltera Felsensteina řídilo zákonitostmi a tvůrčími procesy divadla činoherního (FELSENSTEIN, FRIEDRICH a HERZ 1970: 71$).{ }^{39}$

Jak známo, Stanislavskij do teoretických a pedagogických úvah zahrnoval také operu, kterou měl během svých mladých let v popředí zájmů. ${ }^{40}$ (Zde můžeme dodat, že Felsenstein se k operní režii dostal zase přes činohru.) Stanislavského názory na základní otázky operní režie se s východisky Waltera Felsensteina nacházely v pozoruhodné shodě. Oba kupř́kladu požadovali, aby se způsob jevištní interpretace odvíjel od partitury (Felsenstein ji označoval jako „nejobsažnější režijní knihu“), nebot v ní, a nikoli pouze v libretu tkví podstata inscenovaného díla. Stanislavskij tvrdil, že úkolem operního režiséra je najít jevištní ekvivalent pro vyjádření významu, který skladatel vložil do každého taktu, do jednotlivé hudební figury. Režisér musí slyšet, jak nástroje „hovoří“. („Mluvíli [...] nástroj o tématu smrti, má také zpěvák odpovídající prožitek." [STANISLAVSKIJ 1954: 298] $)^{41}$ Rovněž Stanislavskij, stejně jako Felsenstein, stavěl do středu uměleckého přetváření díla na scéně nikoli režiséra, nýbrž zpěváka, a zdůrazňoval jeho tvưrčí význam. Podle Stanislavského se úloha herce nevyčerpává tím, že vnějšně napodobí postavu; Felsenstein hovořil přímo o „tvưrčím dokomponování a dobásnění díla“ pěveckým představitelem (FELSENSTEIN 1976: 37).

Pokud Kehrmann v knize jméno slavného ruského divadelníka vůbec zmiňuje, pak spíše zdůrazňuje ideologické kontroverze, které se vedly kolem dogmatizace Stanislavského systému a ve kterých Felsenstein významně figuroval. Roku 1953 se v rámci několika různých schůzí sekce dramatických umění při Akademii umění NDR jednoznačně vyslovil proti absolutizování Stanislavského metody v současném východoněmeckém umění; v potaz se podle něj měly vzít také jiné divadelní metody a př́stupy, nevyjímaje ty, s nimiž pracovali divadelníci NSR. ${ }^{42}$

39 FRIEDRICH, Götz. Die Ausgangsituation im Musiktheater.

40 Původně chtěl být operním zpěvákem. V roce 1918 pak založil operní studio, ve kterém vytvořil řadu inscenací, mj. inscenaci Čajkovského Evžena Oněgina (1922) či Musorgského opery Boris Godunov (1929).

41 Beseda u příležitosti otevření Státního operního studia - Divadla K. S. Stanislavského, dat. 23. 11. 1926.

42 Srov. protokoly ze schůzí cit. in (KEHRMANN 2015: 1019). 
Kritický postoj vůči snahám „zglajchšaltovat“ uměleckou tvorbu podle zásad (socialistického) realismu dával Felsenstein najevo za zavřenými dveři, ale i v rámci veřejných vystoupení, zejména pak při jednáních sekcí Akademie der Künste, jíž byl členem od roku 1952 (o čtyři roky později mu pak byla přidělena funkce viceprezidenta). V tomto prostředí se mohl vyjadřovat otevřeněji. Několik pádných důkazů nekompromisního uměleckého postoje podal v době, kdy se vedly boje o prosazení stalinských metod do německé kultury. Za připomenutí stojí jeho angažmá ve prospěch dvou významných představitelů soudobého umění. V květnu 1953 se při jednání zástupců všech sekcí Akademie umění jako jediný (!) zastal Hannse Eislera v rámci zuřivé debaty kolem jeho plánované opery Johann Faustus. Předmětem kritiky se stalo skladatelovo libreto, v němž měl Eisler dle oficiálního stanoviska vytvořit negativní obraz Fausta a dehonestovat tak národní hrdinskou postavu klasika německé literatury Goetha. ${ }^{43}$ Felsenstein ostře odsoudil agresivní a osobně motivovaný výpad Ernsta Hermanna Meyera a Wilhelma Girnuse; ${ }^{44}$ měl dokonce prohlásit, že Eislerovo dílo po jeho dokončení rád provede v Komické opeře. ${ }^{45}$ A rozhodný postoj zaujal rovněž v prosinci téhož roku během jednání sekce dramatických umění, když se otevřeně vyslovil proti tomu, aby se státní kulturní orgány vměšovaly do výukové koncepce taneční školy Grety Palukky v Drážd’anech. ${ }^{46}$

\section{Jak realistické je „realistické hudební divadlo“?}

Kehrmann se v knize pochopitelně nespokojuje pouze s Felsensteinovými proklamacemi, jež problematizují vžitý úzus v charakteristice jeho konceptu hudebního divadla jako „realistického“; pro své závěry hledá a nalézá oporu také v inscenační tvorbě režiséra. Jakkoli postupuje méně systematicky než v jiných částech výkladu a zmiňuje pouze pár namátkových příkladů, inspiruje čtenáře přinejmenším k zamyšlení, lze-li na Felsensteinovo jevištní dílo vztáhnout stylový pojem realismus a s jakými otázkami se přitom musíme vypořádat.

43 Děj se odehrává v době Německé selské války v 16. století. Faust, ačkoli vzešel z rolnické vrstvy, odmítne podpořit své souputníky, kteří povstanou proti feudálům, a svým paktem s Mefistofelem zaručí aristokracii konečné vítězství v boji proti sedlákům. Představitelé oficiální kultury považovali Eislerovo vyobrazení Fausta za „pesimistické“, „bezvýchodné“ či „antinárodni““ a roli, kterou svému intelektuálnímu hrdinovi přisoudil, za nežádoucí z hlediska nového, socialistického výkladu německých dějin. Srov. k tomu více (KEHRMANN 2015: 1022-1023).

44 Ernst Hermann Meyer (1905-1988), hudební skladatel a muzikolog, jeden z předních reprezentantů socialistického realismu v hudbě NDR (patřil k zakládajícím členům Akademie der Künste, v letech 1965-1969 byl jejím viceprezidentem). Wilhelm Girnus (1906-1985), literární vědec, autor řady prací (mj. o Goethovi), zaměřených v marxisticko-leninském duchu (v letech 1953-1955 byl vedoucím odboru krásné literatury a umění ústředního výboru Sjednocené socialistické strany Německa).

45 Podobně vstř́ícný postoj zaujal k Dessauově dodekafonické opeře na Brechtův text Pan Puntila a jeho služebník Matti (1959) - od záměru uvést dílo v Komické opeře nakonec upustil, nebot si s ním po režijní stránce nevěděl rady (KEHRMANN 2015: 62).

46 Gret Palucca (1902-1993), tanečnice a taneční pedagožka, světově proslulá představitelka výrazového tance. Jako vedoucí Taneční školy v Drážd’anech vedla letitý zápas s kulturními představiteli DDR, kteří se snažili utlumit její experimentální tendence a taneční umění přizpůsobit postupům ruského klasického baletu. V roce 1959 emigrovala do západního Německa, ale jako světově uznávané umělkyni se jí podařilo vyjednat podmínky návratu (roku 1960 byla dokonce vyznamenána Národní cenou NDR). 


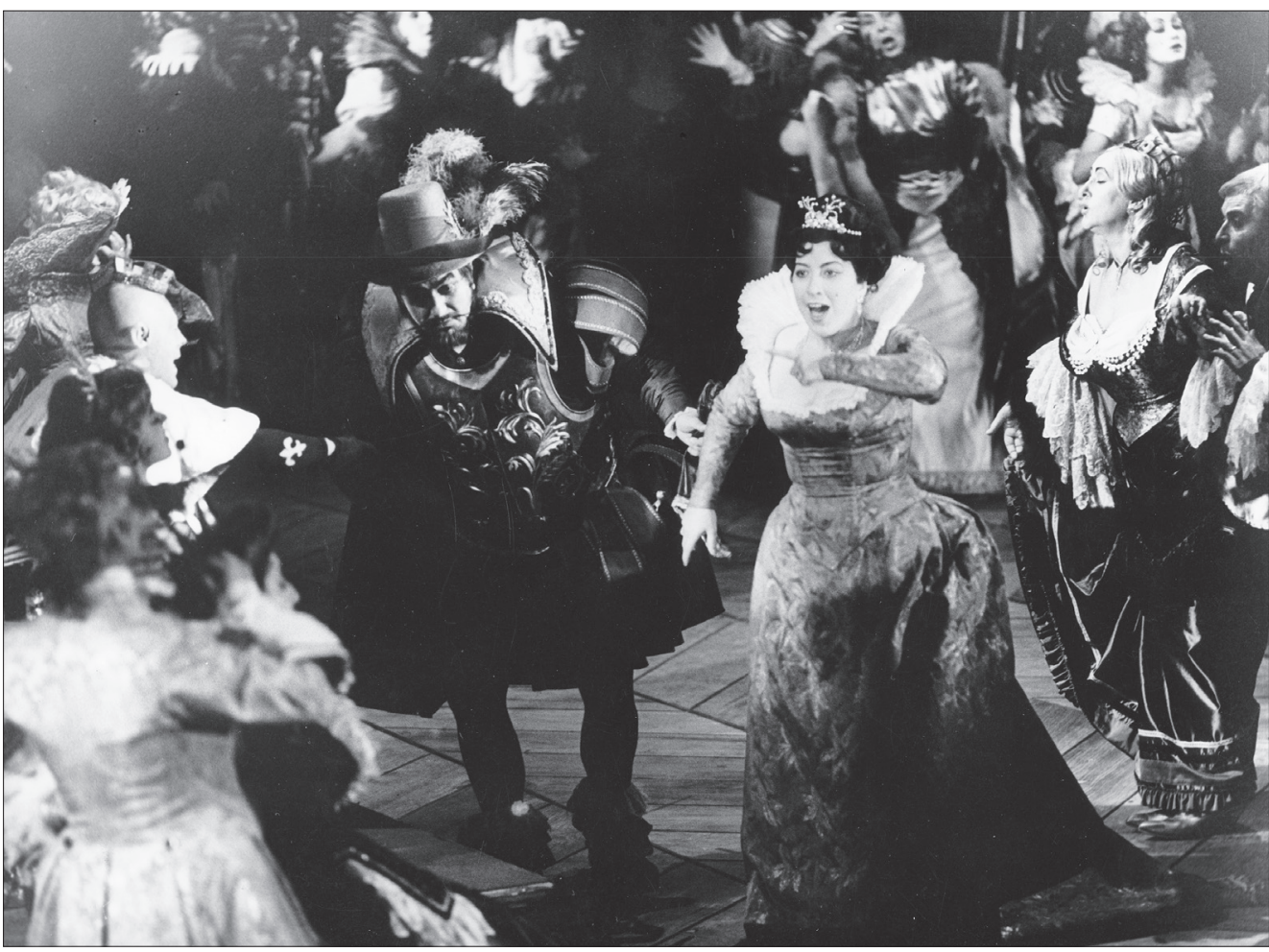

Obr. 2: Jacques Offenbach: Rytír Modrovous (Ritter Blaubart), Komická opera v Berlíně, 1963. Uprostřed Hans Nocker (Modrovous) a Anny Schlemm (Boulotte). (Akademie der Künste, Berlin, Walter-Felsenstein-Archiv, sign. 1689_05. Foto: Willi Saeger. Copyright Deutsches Theatermuseum München).

Pokus o klasifikaci Felsensteinova inscenačního stylu totiž ovlivňuje několik zásadních faktorů. Definujeme-li realismus na divadle jako styl, jenž je spjat s úsilím o co nejvěrnější nápodobu skutečnosti za pomoci výtvarných, hereckých či hudebních prostředků, ihned se nabízí otázka, můžeme-li v těchto intencích vůbec uvažovat v případě žánru, jakým je opera. Ve světle vysoce stylizované operní formy, v níž zpěv posouvá komunikaci a jednání nutně do sféry umělé reality, nelze označení „realistické“ operní či hudební divadlo vnímat jinak než jako contradictio in adjecto. Ponecháme-li stranou otázku, je-li vůbec realizovatelná nápodoba skutečnosti na scéně tak, aby divák dosáhl dojmu, že sleduje skutečnost samu, dostaví se pochybnosti nad našimi poznatky o tom, jaká vlastně byla konkrétní podoba realismu v divadle 19. století. Víme kupř́íladu, jakým zpo̊sobem a do jaké míry se herec dokázal „identifikovat“ se svou postavou?

Zůstaňme navzdory našemu nedostatečnému povědomí o podobě divadelního realismu jako stylu v umění 19. století u pojmenování Felsensteinovy tvorby jako realistické, čímž na sebe bereme další rizika ahistorického pohledu. Musíme vést v patrnosti, že k hodnocení stylu jeho inscenací přistupujeme z perspektivy inscenačního vývoje 
v evropském divadle uplynulých padesáti let. Je zřejmé, že ve srovnání s prudkým rozvojem tzv. režijní opery, jejíž nástup se v německém prostředí zhruba překrývá se závěrem Felsensteinova života, nám bude výtvarný styl Felsensteinových inscenací připadat jako vyžilý, málo imaginativní a ve více jeho jevištních ztvárněních pravděpodobně i „stejný“, což může podporovat dojem realistického pojetí. Podobně dopadne ve srovnání s dobovým výtvarným abstrakcionismem v inscenacích Wielanda Wagnera v sousedním západním Německu. V hereckém ztvárnění, které tvoří stěžejní bod Felsensteinova „realismu“, budeme postrádat škálu př́stupů, jež zastřešujeme nepřesným výrazem „stylizované herectvi“ a s jejichž pomocí mnozí režiséři ještě více „zdivadelňuji“ operní žánr. Na druhé straně nelze opominout ani opačné tendence v současném operním divadle, jejichž snahou je eliminovat „nepravděpodobnost“ opery jako takové a přiblížit ji co nejvíce běžné realitě. Např́iklad nedávná inscenace Janáčkovy opery $Z$ mrtvého domu $\mathrm{v}$ interpretaci jednoho z nejradikálnějších operních režisérů současnosti Calixta Bieita ${ }^{47}$ byla vzorovou ukázkou stylu, který si nejspíše činí ambice působit z hlediska stylu drsným naturalismem. Ačkoliv se tyto tendence či právě spíše ambice výrazně projevují zejména v herecké, režijní a kostýmní složce, ${ }^{48}$ za naturalismus je označit nelze. Spíše bychom mohli hovořit o tendenci realistické, nikoliv však důsledně naplňované - rozhodně ne ve smyslu realistického stylu konce 19. století. S Felsensteinovým operním stylem, jenž se Joachim Herz nerozpakoval označit jako „poetický“ či „magický“ realismus, ${ }^{49}$ takové pojetí však nemá nic společného. Posunume-li se na historické ose o několik desetiletí zpět, ve světle převažující praxe tradičního operního inscenování včetně neměnných konvencí v operním herectví se Felsensteinova snaha nutně musela dobovému publiku jevit jako projev realismu (v širším slova smyslu). V operním divadle, které demonstruje př́klon $\mathrm{k}$ činohře, kde zpěv aspiruje na funkce mluveného slova a vše je podř́zeno hodnověrnému ztvárnění hudebně dramatické situace, pochopitelně značně vzrostl význam režiséra - z tohoto pohledu může být Felsensteinovo hudební divadlo dodnes vnímáno jako inovativní, což potvrzují i režiséři jako Joachim Herz, Götz Friedrich, Harry Kupfer či Ruth Berghausová. Všichni jmenovaní se u Felsensteina učili operně režijnímu řemeslu a jakkoli rozvíjeli jeho postupy později jiným směrem, zůstal pro ně jedním z prvních iniciátorů oné tendence, již označujeme jako režijní opera (HINTZE, RISI a SOLLICH 2008: 50). ${ }^{50}$

47 Premiéra se uskutečnila 12. 3. 2016 ve Státním divadle v Norimberku, české publikum se s inscenací mohlo seznámit v rámci mezinárodního festivalu Janáček Brno 2016. Španělský režisér Calixto Bieito $(* 1963)$ má na svém kontě několik skandálních inscenací a patří $\mathrm{k}$ nejdiskutovaněǰším divadelním režisérům současnosti. V jeho inscenacích „teče krev“ a močí se přímo před zraky diváků nebo se v nich s oblibou provozuje masturbace či orální sex (takto si kupřr. krátí čas ve vězení postavy zmíněné Janáčkovy opery). Jedna část odborných kritiků Bieitův nonkonformní postoj k opeře schvaluje, mnozí však poukazují na jeho často povrchní přístup k inscenovanému dílu a oblíbené jevištní postupy vnímají jako projev marketingové strategie, doprovázené vysokou publicitou jeho inscenací.

48 Z hlediska pojetí scény byli inscenátoři - i přes přítomnost realistického vraku letadla - v množství výrazových prostředků již ekonomičtější.

49 Srov. (HINTZE, RISI a SOLLICH 2008: 50). HERZ, Joachim. „Einer von den kleinen Felsensteinen...“. Vom Erben, vom Weiterreichen und vom Vergessen.

50 Viz kupř. př́íspěvky Joachima Herze, Gerda Rienäckera či Bettiny Brandl-Risi. 
V rámci studia Felsensteinových inscenací se potýkáme se základním metodologickým problémem, a totiž neexistencí nejdůležitějšího pramenu v podobě živých představení, jež tento režisér v letech 1947-1975 vytvořil v Komické opeře. Později vzniklé operní filmy, které v roce 2009 vyšly jako DVD edice, ${ }^{51}$ nelze považovat - bez ohledu na jejich nezpochybnitelnou poznávací hodnotu a význam z hlediska historické dokumentace za věrohodný obraz Felsensteinových jevištních děl. Ještě více to platí pro záznamy, které netočil v autentickém prostředí jeviště, nýbrž ve filmovém studiu (Othello, Hoffmannozy povidky, Rytǐr Modrovous a Liška Bystrouška). ${ }^{52}$ Jako konfrontační materiál slouží alespoň v omezené míře dochované úryvky a zpravodajské šoty z autentických operních představení, které jsou ve formě bonusových materiálů součástí edice. Poznatky o filmové podobě inscenací pak lze porovnat rovněž s recenzemi na uvedení v Komické opeře, z nichž se dá získat překvapivě rozmanitý vzorek dobové recepce Felsensteinova inscenačního stylu. Vyplývá z nich, že za realistické byly považovány inscenace Othella nebo Lišky Bystroušky, Felsensteinovy offenbachovské inscenace či kupř. jevištní ztvárnění Orffovy Chytračky a Brittenova Snu noci svatojánské se ale této klasifikaci vymykaly pro jejich antiiluzivní postupy v jevištní výpravě i herectví.

Kehrmann připomíná, že kolosální efekt bouře v Othellovi (1. jednání) působil nutně jinak ve studiovém snímku s využitím důmyslné střihové skladby s detailním pohledem do zděšených a živlem zmítaných tváří „lidové masy“ než jako součást přiznané scénické reality. Rovněž ve filmové podobě Hoffmannových povídek byl divák ochuzen o divadelní rozměr původní inscenace, která podtrhávala hru několika úrovní reality vyprávěného příběhu (zvýrazněným portálem se publikum nepřetržitě konfrontovalo s realitou představení). ${ }^{53} \mathrm{U}$ některých filmových ztvárnění jeho inscenací, zejména pak u Offenbachova Rytíre Modrovouse obsahujícího aktuální politické aluze, byla citelně znát absence interaktivní spolupráce mezi účinkujícími a publikem.

U Hoffmannových povidek můžeme celkově hovořit o propastném rozdílu mezi originálním jevištním dílem ${ }^{54}$ a jeho filmovým ztvárněním. Z původní fantastiky a poetičnosti zde mnoho nezbylo. Světelnou koncepci představení, dodávající dění na scéně takřka kafkovsky přízračnou atmosféru, nebylo možné převést do filmové podoby. Felsenstein byl nucen změnit značný díl výpravy jak k Hoffmannovým povidkám, tak především k druhému Offenbachovu dílu, operetě Rytír Modrovous, ${ }^{55}$ aby zmírnil grotesknost

51 Srov. Walter Felsenstein Edition (12 DVDs), Arthaus Musik GmbH, 2009.

52 Mozartovy opery Don Giovanni a Figarova svatba natáčel Felsenstein jako záznam z jevištního provedení. Jedině Fidelio byl od počátku zamýšlen jako film a byl realizován v několika lokacích.

53 Melchingerovi k tomuto řešení Felsenstein prozradil, že záměrem bylo ostře rozlišit jeviště a hlediště, a narušit tak dojem realističnosti. „[...] za čiernym portálom se opät vynorila divadelná architektura, a to v plynových kandelábroch. Tak sme vedome pomiešali dojem realističnosti, ktorý mal vyplynút z ostrého rozlíšenia javiska a hladiska, s prvkom fantastickým, ktorý zase tento realizmus stieral.“ (FELSENSTEIN a MELCHINGER 1964: 54).

54 Srov. Hoffmanns Erzählungen, Wochenschaufilm von 1958 jako součást DVD edice (J. Offenbach: Hoffmanns Erzählungen).

55 Část pramenů k inscenaci Blaubarta rovněž obsahuje edice DVD (J. Offenbach: Ritter Blaubart). Kromě fotografií a návrhů scény a kostýmů jsou součástí dvě ukázky z prvního aktu, natočené v rámci představení v Komické opeře. 


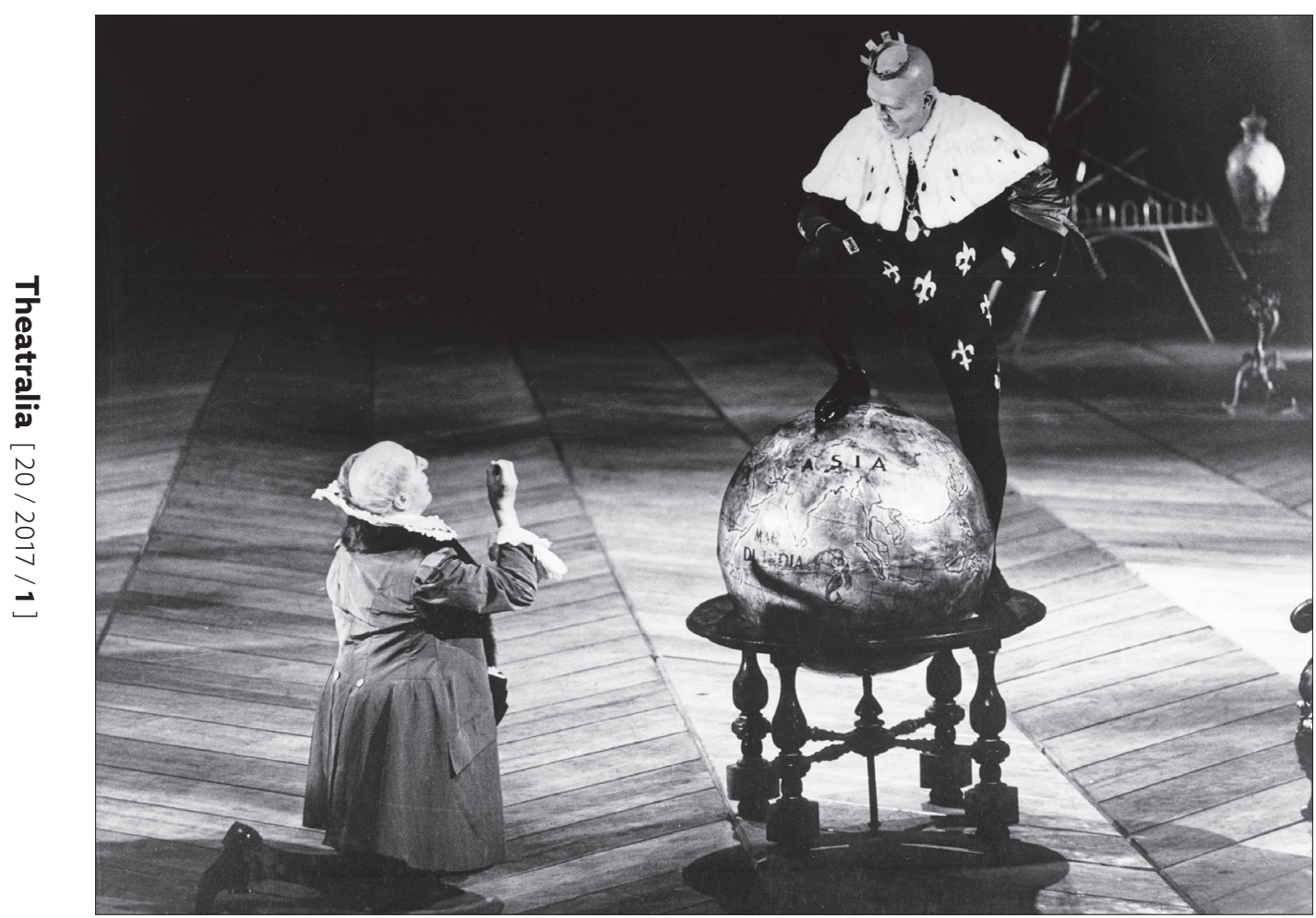

Obr. 3: Jacques Offenbach: Rytír Modrovous (Ritter Blaubart), Komická opera v Berlíně, 1963. Zleva Josef Burgwinkel (Hrabě Oscar) a Werner Enders (Bobèche). (Akademie der Künste, Berlin, Walter-Felsenstein-Archiv, sign. 1689_04. Foto: Willi Saeger. Copyright Deutsches Theatermuseum München).

parodických kostýmů (a masek), která by ve filmovém ztvárnění vyznívala nepatřičně; tím ovšem zmizelo ono imaginativní a nereálné, které z jevištního originálu naopak vyzařovalo. Také herectví doznalo změn směrem ke zcivilnění projevu (dochované ukázky z původních inscenací jmenovaných Offenbachových děl dokládají, že Felsenstein vedl pohyby, gesta a mimiku postav k výraznější nadsázce a karikatuře zpo̊sobem typickým pro expresionistický styl).

Jestliže pro Felsensteinovy inscenace z dvacátých a třicátých let byl př́mo charakteristický nadsazený gestický i mimický výraz, pohyb blížící se tanci a uplatnění karikatury v maskách a kostýmech, offenbachovské inscenace v Komické opeře představovaly onu linii jeho poválečné jevištní tvorby, v níž se nejvíce projevila kontinuita s předešlou poetikou. Výraznou stylizací v herectví se vyznačovala zejména inscenace Rytíre Modrovouse. Pro postavu mocí posedlého krále Bobècha vytvořil Felsenstein drastickou karikaturu, kterou Werner Enders dokázal ztvárnit do nejmenších nuancí (publiku neunikly narážky na slavný Chaplinův film Diktátor včetně převzaté dikce parodující Hitlerův řečnický styl) (KEHRMANN 2015: 718). Inscenace byla příkladem, že pravdivost a věrohodnost se u Felsensteina nerovnala nápodobě reálné skutečnosti na scéně. („Existuje 
také zprostředkování pravdivosti bez evokování skutečnosti. V rámci čisté hry, která zůstane jako hra rozpoznatelná. “56) Ironické zlomy a překreslení v podání postav Bobècha, Modrovouse či Popolaniho považoval Felsenstein za zákonité vzhledem k autorovu záměru zobrazit společenskou deformaci člověka.

Jen za polovičně pravdivou můžeme považovat informaci, že s herci pracoval v duchu realisticky pojatého herectví, a to i například u inscenace Figarovy svatby (1975). Kehrmann uvádí jako příklad Zuzančinu Rosenárii (4. jednání, 10. scéna). Zuzana se chce za každou cenu pomstít Figarovi za jeho bezdůvodnou žárlivost a sehraje vyznání lásky hraběti. Ví, že ji Figaro pozoruje z úkrytu. Felsenstein ve ztvárnění této situace usiloval o to, aby každý divák pochopil, že tato árie není ve skutečnosti Zuzančiným vyznáním lásky hraběti Almavivovi, nýbrž Figarovi, jehož obraz má mladá žena v myšlenkách před sebou. Na záznamu (posthumně 1976) vidíme, kterak interpretka Ursula Reinhardt-Kiss zpívá s rukama rozpřaženýma směrem doprava, odkud je očekáván příchod hraběte, pak ale zapomene na pomstu a postupně se natáčí doleva - směrem k Figarovi, kterého ale nemá spatřit, byt’ sedí v jeho blízkosti (KEHRMANN 2015: 53).

Stojí za zmínku, že Kehrmann zpochybňuje jako realistický i způsob herectví v inscenaci Liška Bystrouška, která bývá považována za nejvýraznější př́íklad Felsensteinovy iluzivní jevištní poetiky. Lze pokládat za realistické, ptá se Kehrmann, když představiteli zviřete přiřadil Felstenstein lidskou postavu, charakterizovanou stejným gestem? Divák měl za maskami zvírat stále vidět zpěváky, kteří tato zviŕata představují, a identifikovat v nich lidské postavy př́iběhu. Werner Enders tak hrál nejen ustrašeného Rechtora, ale také bitého psa Lapáka, Josef Burgwinkel představoval nejen z vesnice vyháněného Faráře, nýbrž rovněž Jezevce, vyhnaného z nory, Adelheid Müller pak představovala nejen bigotní ženu revírníkovu, ale také bigotní sovu. Irmgard Arnold jako Liška se zrcadlila silnou touhou po erotické svobodě v Terynce Helgy Naujok, Georg Baumgartner jako Lišák v roli Harašty (Herbert Rössler) a liščata v revírníkově synu a jeho kamarádech. Za chováním zvírat tak divák mohl neustále vnímat zcizený obraz lidského chování s jeho typickými znaky (KEHRMANN 2015: 53-54). Obdobně bychom se mohli ptát, co lze považovat za realistické na obsazení Oberona a Titanie v Brittenově Snu noci svatojánské černošskými zpěváky. Nešlo spíše o divadelní znak, kterým podtrhl odlišnost světa duchů od ř́ŕse lidí?

Z recenzí a ohlasů na Felsensteinovu předválečnou tvorbu můžeme soudit, že jeho inscenace $\mathrm{z}$ té doby doprovázela všudypř́itomná snaha o antiiluzivní herectví i náznakové výtvarné řešení - záměrem bylo podtržení fantazijnosti a umělého charakteru divadelní reality. Také $\mathrm{v}$ rozhovoru s Melchingerem z počátku šedesátých let uvedl, že nemá rád na scéně nic, co by bylo navíc - nadbytečné nazývá dekorací, jež se mu v zásadě „hnusí“ (FELSENSTEIN a MELCHINGER 1964: 53). V roce 1971 se vyznal ze své náklonnosti k „prázdnému prostoru“, ke zkoušení v civilu, bez masek a paruk, bez dekorací, jen mezi dřevěnými latěmi, nebot to podle něj u zpěváka vede k přesnějšś dramatické výpovědi (KEHRMANN 2015: 42). Felsenstein se evidentně snažil o podřízení všech elementů scény dramatickému vyjádření, které zprostředkoval zpěvák. Výtvarná

56 Citováno na základě diskusního př́spěvku Joachima Herze, otištěného in (HINTZE, RISI a SOLLICH 2008: 62). 
podoba scény měla být taková, aby neodváděla pozornost jinam. Důsledně realistická výprava Lišky Bystroušky ${ }^{57}$ byla spíše výjimkou, v ostatních inscenacích dával přednost stř́zlivému náznaku prostředí děje.

Využíval i prvky, jimiž udržoval dojem divadla jako umělé reality. Zadní prospekt s perspektivní iluzionistickou malbou, jak jej uplatnil v Donu Giovannim, nebyl ničím více než citací barokní divadelní konvence. „Realismus není hraní reality, nýbrž hraní hry“, uvedl Melchinger ve svém článku „Die Bühne des Don Giovanni““. ${ }^{58}$ Bylo by naivní přesvědčovat diváka, že se nachází na ulici v Seville nebo v paláci, když je přece nadmíru zřejmé, že sedí v hledišti divadla. Z fotografií k inscenaci Figarovy svatby kupř. vyplývá, že ve 4. jednání, odehrávajícím se ve večerním parku, Felsenstein nevytvořil v souladu s požadavkem realistické iluze setmělý prostor, ale nechal scénu zasvítit. Také zámek hraběte v sobě neměl mnoho realistického; okna a dveře stojí uprostřed prázdného prostoru (postup typický pro některé jeho inscenace z doby před založením Komické opery) a jsou čistě funkčním prvkem (KEHRMANN 2015: 41). Felsenstein takovéto prostorové uspořádání označoval jako „Lichtraum“ (KEHRMANN 2015: 41) neboli světelný prostor: divák měl vidět, kdo se blíží k místu děje či kdo se ukrývá za dveřmi. Výtvarník Reinhart Zimmermann shrnul výtvarnou koncepci Figarovy svatby následovně:

Citujeme do detailu, pokud to děj vyžaduje. [...] Architektura a prostředí jako atmosféra nehrají žádnou roli. Velké téma se odehrává v nejmenším okruhu a okolí se do něj nedostane. Co má být řečeno, vyřknou postavy a hudba; není důvod k tomu ještě něco „ukazovat“. Důležité je, že komplikovaný a turbulentní děj se uskutečňuje v prostoru, který je jasný a světlý. Tak vznikla scéna ze světla a bílé barvy, v níž dominuje jednající člověk. (citováno dle KEHRMANN 2015: 41-42)

Významný kritik Ernst Krause z NDR se v západoněmeckém časopisu Opernwelt vyjádřil o nerealistickém dějišti Felsensteinovy inscenace, z níž prý režisér vypudil „,jakékoli př́ijemné operní rokoko, jakékoli dekorativní umění, už jenom pouhý náznak zdání“ (KRAUSE in KEHRMANN 2015: 42). ${ }^{59}$

Dále je možné jako prŕklad Felsensteinova stylizovaného řešení ve výpravě uvést surrealisticky pojatou scénu a kostýmy Rudolfa Heinricha pro inscenaci Sen noci svatojánské. V Prokofjevově Lásce ke třem pomerančum podle Gozziho hry umístil do středu jeviště malé vyvýšené pódium a princip divadla na divadle ještě umocnil tím, že scénu z obou stran uzavřel výsekem lóží Komické opery, do nichž usadil sbor. Zpěváci, oblečení do pestrobarevných kostýmů osobitého střihu, využívali jen nejdůležitější rekvizity, které byly důmyslně vkomponovány do dynamické herecké akce, vycházející z tradic komedie dell'arte. Recenzent Hudobného života Branislav Kriška, který představení zhlédl v rámci Berliner Festtage v roce 1970, přímo konstatoval, že „jevištní pravdou“ se tu

57 Felsenstein měl s výtvarníkem Rudolfem Heinrichem v záloze ještě i další, podstatně méně realistická prostorová řešení pro inscenaci Janáčkovy opery, než jaké nakonec zvolili.

58 MELCHINGER, Siegfried. 1966/67. Die Bühne des Don Giovanni. Jahrbuch der Komischen Oper VII (1966/67): 137. Cit. dle (KEHRMANN 2015: 43).

59 KRAUSE, Ernst. 1975. Aufregender, junger Figaro. Opernwelt (1975): 4: 27. Cit dle (KEHRMANN 2015: 42). 
stala divadelní poezie a metafora: „Ani stopy po akomkolvek náznaku naturalizmu či podriadení ktorejkolvek zložky operného diela. Zato velké umenie inscenátorov, ktorí s viditelnou vierou v detsky naivnú, ale krásnu fantáziu vytvárajú večer plný poézie, radosti a zázrakov pre dospelé deti v hladisku - i pre seba!“ (KRIŠKA 1970: 8)

\section{Domácí recepce Felsensteinovy inscenační tvorby}

Bezprostřední kontakt s výsledky inscenační práce Waltera Felsensteina zprostředkovalo českým divákům až první hostování Komické opery v rámci festivalu Pražské jaro. Uskutečnilo se v týdnu od 20. do 27. května 1956 a soubor v Praze představil inscenace Straussovy Mlčenlivé ženy a Weberova Čarostřelce. ${ }^{60}$

Jen o pár dnů později, 30. května, uvedl Felsenstein v Komické opeře inscenaci Lišky Bystroušky s budoucí pěveckou hvězdou ansámblu Rudolfem Asmusem v roli Revírníka. Domácí publikum se s tehdy ojedinělou interpretací Janáčkovy opery mohlo seznámit až roku 1962; ve Smetanově divadle byl opět v rámci Pražského jara uveden ještě i Othello.$^{61}$ Při př́ležitosti hostování Komické opery v Praze udělila Karlova univerzita Walterovi Felsensteinovi čestný doktorát. Walter Felsenstein se stal v českých operních kruzích fenoménem, připomínán byl také jeho vstřícný vztah k našim interpretům do Komické opery angažoval kromě Rudolfa Asmuse ${ }^{62}$ rovněž Jarmilu Kšírovou, ${ }^{63}$ Vladimíra Bauera, ${ }^{64}$ Jaroslava Kachela ${ }^{65}$ Janu Smítkovou ${ }^{66}$ a v sedmdesátých letech ještě i Klemense Słowioczka. ${ }^{67}$

Soustavnější domácí reflexi Felsensteinovy koncepce hudebního divadla a jeho inscenačních děl můžeme pozorovat od počátku 60. let, přičemž je zřejmé, že největší

60 Nejpodrobněji se k nim vyjádřila Jarmila Brožovská v recenzi pro časopis Divadlo (BROŽOVSKÁ 1956).

61 Představení Janáčkovy opery se konalo 27. a 29. května, představení Othella 24., 26. a 28. května.

62 Rudolf Asmus (1921-2000) byl Felsensteinem angažován v roce 1956 a v Komické opeře setrval do konce života (od roku 1988 byl jejím čestným členem). Vyjma Othella a Carmen (1972) hrál ve všech Felsensteinových inscenacích.

63 Jarmila Kšírová (1910-1983) byla členkou ansámblu Komické opery v letech 1948-1967. Jako svou první roli zde ztvárnila Carmen (1949), v dalších inscenacích režírovaných Felsensteinem se ujala role Metelly v Pařžžkém životě (1951) a Jenty v muzikálu Šumař na stř̌še (1971).

64 Vladimír Bauer (1925-1991) byl angažován roku 1959 a členem Komické opery byl až do své smrti. Hrál významné role ve Felsensteinových inscenacích Othello (Jago), La traviata (Germont), Hoffmannovy povídky (Spalanzani) a Rytî́r Modrovous (Popolani - v alternaci s Rudolfem Asmusem).

65 Jaroslav Kachel (1932-2007) působil v Komické opeře jako člen ansámblu v letech 1962-1971. První rolí, kterou ztvárnil, byl Othello (v alternaci s Hannsem Nockerem, se kterým alternoval také v roli Modrovouse a Lazara Wolfa z muzikálu Šumař na střeše).

66 Jana Smítková (1942) přijala angažmá roku 1973 na základě účinkování v titulní roli Herzovy inscenace Káti Kabanové. Jako Micaela (Carmen) a Örzse (Háry János) účinkovala v inscenacích Felsensteina. V Komické opeře působila do roku 1993.

67 Klemens Słowioczek (1945) získal angažmá roku 1975. Při předzpívání v pražském Národním divadle si jej pro roli Figara vybral sám Felsenstein, který v něm prý viděl druhého Asmuse (proti původnímu plánu však premiéru nezpíval a v inscenaci vystupoval až po Felsensteinově smrti). Své působení v Komické opeře ukončil roku 2005. 
počet článků vyšel v roce 1962 v souvislosti s diskusemi o inscenaci Janáčkovy opery. V recenzích se zdůrazňovala vysoká profesionalita režijní práce a výkonů celého souboru, která byla dávána za příklad domácím operním divadlům. Fascinaci přísným vedením souboru a disciplínou zpěváků vyjádřili Eva Herrmannová s Vladimírem Léblem, kteří se účastnili zkoušek na představení Lišky Bystroušky u příležitosti pražského uvedení:

Felsensteinovy zkoušky jsou koncertem tvưrčí fantazie, pevné logiky, pracovní soustředěnosti a jedinečné kolektivní discipliny. Improvizace a náhodnost jsou v Komické opeře vyloučeny, tady se promýšlí a pevně fixuje každý pohyb, každé gesto, každý výrazový odstín. Od operního pěvce se vyžaduje akrobatické zvládnutí role: všechno fyzické jednání musí přejít do krve, musí se při představení vybavovat se stejnou samozřejmostí, s jakou artista provádí životu nebezpečný cvik. Představitel učitele v Lišce má svo̊j pád nacvičen a vypočítán na půlmilimetr přesně; obtíže pěveckého řemesla mizí zásluhou nekonečného počtu zkoušek, všechny reakce jsou automatické, pěvec se může dokonale soustředit na vrcholný tvůrčí akt prožívání. (HERRMANNOVÁ a LÉBL 1962: 1)

Někteří kritikové si povšimli, že po pěvecko-technické stránce nebyly výkony interpretů Komické opery vždy zcela bezchybné, což jen potvrzuje známý fakt, že v inscenacích, které Felsenstein režíroval, bylo na prvním místě herecké vyjádření dramatického děje. Pokud bylo Felsensteinovi opravdu něco vytýkáno, pak většinou popisnost výpravy. Hudební kritikové také poukazovali na interpretační odchylky oproti hudební partituře; diskutovalo se kupříkladu o tom, zdali je možné, aby režisér měnil skladatelem předepsanou melodii a nahrazoval ji parlandy, neintonovanými výkřiky a jinými projevy na pomezí zpěvu a mluvy. ${ }^{68}$ Jednu z typických výhrad shrnul Jiří Bajer v zamyšlení „Achillova pata Komické opery?“. Položil otázku, není-li schopnost režiséra vypracovat jevištní tvar do nejmenšího detailu a doslovit významy operního díla do definitivní „pravdy“ vlastně limitujícím faktorem uměleckého zážitku, nebot divákovi tu není ponechán nejmenší prostor k samostanému domýšlení významů (BAJER 1962). ${ }^{69}$ A někteří recenzenti rozvíjeli své výhrady dál; objevily se i pochybnosti, jestli slavný německý režisér vlastně divadlem neutiskuje hudbu. Jaromír Paclt v recenzi „Felsensteinův Othello“, kterou napsal na základě jím zhlédnutého představení Verdiho opery přímo v Berlíně, konstatoval, že Felsenstein se nahromaděním jevištně výrazových prostředků v zájmu „vševyčerpávajícího vyjádření zvukové partitury“ dostal až na hranici možného. Jako názorný př́iklad uváděl legendární scénu bouře: divák nejenže nedokáže smysly kompletně pojmout přesycenost scény detaily, ale výsledkem prý je doslova absence vnímání Verdiho hudby (PACLT 1959). Jiří Bajer k tomu ve výše citovaném článku dodal, že dualita intenzivního hudebního i jevištního vyjádření přináší v konečném důsledku

68 Srov. např. (BAJER 1962), (VOJTĚCH 1962) nebo (HERRMANNOVÁ a LÉBL 1962).

69 V tomto smyslu se vyjádřili také Eva Herrmannová s Vladimírem Léblem, když vznesli námitky proti Felsensteinovu rozhodnutí pozměnit janáčkovskou mnohovýznamovou zkratku a zkrotit jistou naivitu v příběhu o lišce Bystroušce, vybízející však k divákově představivosti, ve jménu př́sné dějové logiky (HERRMANNOVÁ a LÉBL 1962: 1). 


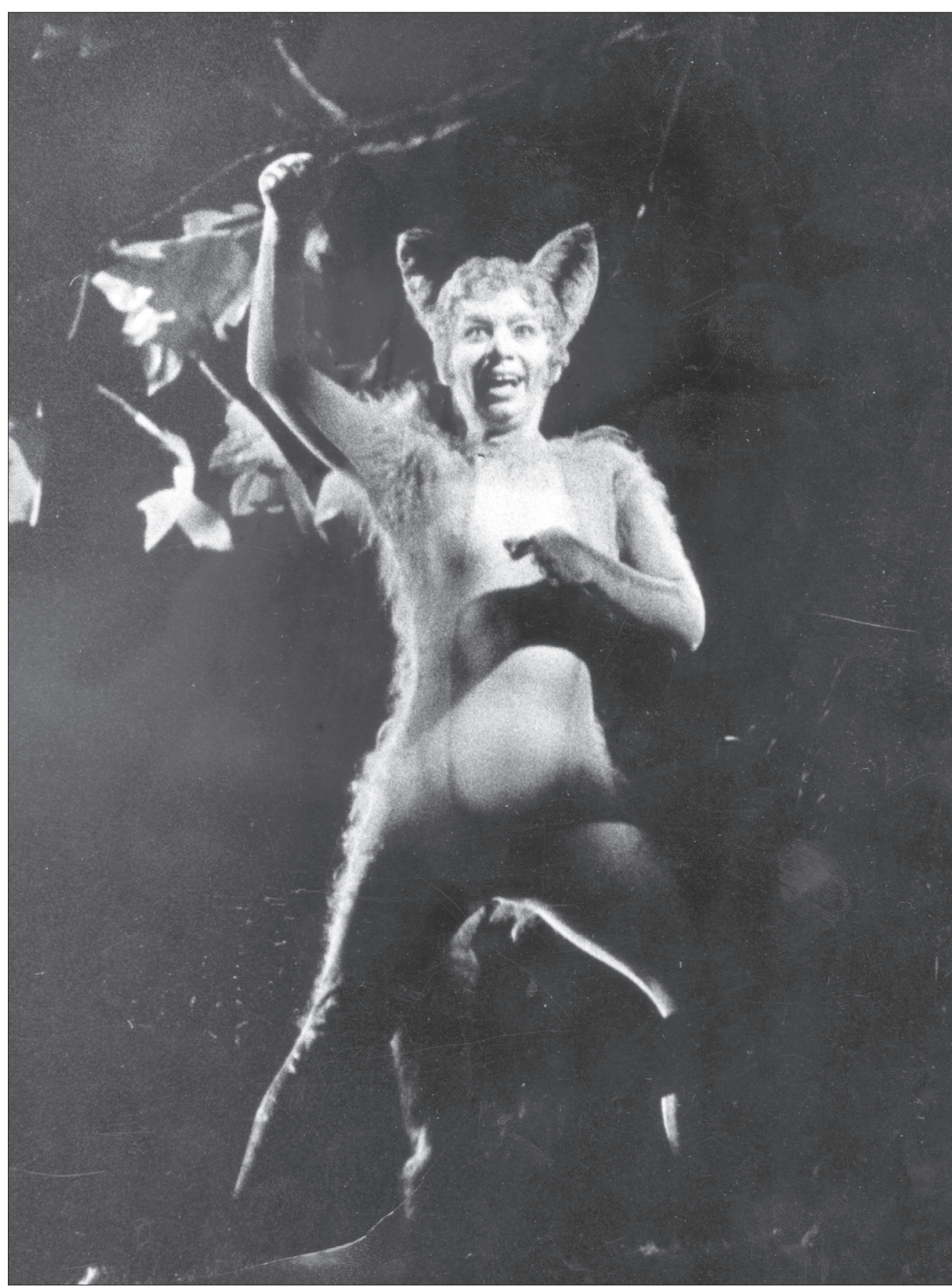

Obr. 4: Leoš Janáček: Liška Bystrouška (Das schlaue Füchslein), Komická opera v Berlíně, 1956. Irmgard Arnold v titulní roli. (Akademie der Künste, Berlin, Walter-Felsenstein - Archiv, sign. 2329. Foto: Jürgen Simon). 
vlastně opačný efekt, než jaký chtěl Felsenstein dosáhnout, totiž že jedna složka potlačí tu druhou (BAJER 1962).

Neuralgickým bodem domácí diskuse nad Felsensteinovým jevištním stylem se pochopitelně stala inscenace Janáčkovy opery, v níž režisér vyzdvihl motiv lásky s důrazem na erotické momenty v jednání zvířecích i lidských postav. Těžiště polemik představovala dramaturgická úprava díla, která byla nesena snahou vnést do příběhu větší dramatičnost, učinit věrohodnější psychologii, vztahy a motivy jednání postav. Felsenstein vyšel z překladu Maxe Broda, který se od originálního libreta znatelně vzdálil. Nejvýraznější změnou bylo akcentování postavy Terynky jako lásky revírníka, rechtora (platonické) i faráře a domyšlení analogie mezi touto ženskou postavou a Bystrouškou. ${ }^{70}$ Felsensteinův zásah do Janáčkovy opery nepřijala naprostá většina českých kritiků, výhrady měli i operní režiséři. Václav Věžník, známý svým pietním vztahem k partituře, označil Felsensteinovu interpretaci ještě i po letech za neomluvitelné nakládání s originálním dílem. ${ }^{71}$ Také kupř. Ladislav Štros, který měl k Felsensteinovi obecně značné výhrady, ji ostře odmítl jako důsledek „chtěné dramatičnosti“ (z jeho pohledu mělo jít o „násilnou dramaturgickou chirurgii, která neodpovídala smyslu díla“) (ŠTROS 1995/96: 23). ${ }^{72}$ Ve jménu větší pravděpodobnosti se Felsenstein rovněž odhodlal k přeobsazení rolí Lišáka, Lapáka a Kohouta, ze kterých udělal role „mužské“. (Tímto řešením se inspiroval ve své pozdější inscenaci z roku 1965 Miloš Wasserbauer, který postavu lišáka Zlatohřbítka rovněž obsadil tenorem.) Domácí kritiku pak dráždila i popisně realistická výprava, což mělo zřejmě souvislost s brněnskou premiérou z roku 1924 v kubistických kostýmech a scénografii Eduarda Miléna, kterou sám Leoš Janáček prý přijal s neskrývaným nadšením. K prvkům naturalismu ve výpravě $\mathrm{k}$ berlínské inscenaci se vyjádřil odmítavě kupř. režisér Václav Kašlík, který tuto operu inscenoval vícekrát (v Německu dokonce třikrát) ${ }^{73}$

Na zpo̊sob výtvarného ztvárnění Janáčkovy opery v památné premiéře z dvacátých let v režii Oty Zítka navázal v roce 1965 tvưrčí tandem Miloš Wasserbauer a František Tröster. Jejich inscenaci lze zároveň považovat za nejvýznamnější režijní příspěvek do diskuse s opusem Waltera Felsensteina. Ani Wasserbauer nesouhlasil s výše zmíněnou dramaturgickou úpravou ve jménu větší dramatičnosti opery (jakkoli on sám obecně proti razantnímu zásahu do skladatelského díla, pokud to režijní koncepce vyžadovala, nic nenamítal). Jestli mu však na Felsensteinovu výkladu Janáčkova díla něco opravdu hodně vadilo, pak to byl iluzivní výtvarný rámec v provedení scénografa Rudolfa Heinricha. Ve svém pojetí se nezříkal v podstatě realistického řešení výstupů ze světa lidí,

70 Paralelu mezi Terynkou a Bystrouškou vyjádřil Felsenstein v prvním jednání, ve scéně Bystrouščina snu, který měl podobu milostného setkání revírníka s Terynkou. A tudíž v momentě, kdy Bystrouška v závěru opery umře, promítne se v divákově vědomí motiv smrti zvířecí hrdinky do osudu revírníkovy lásky k Terynce.

71 Rozhovor Heleny Spurné s Václavem Věžníkem z října 2016 (audionahrávka v soukromém archivu HS).

72 Štros svou vlastní inscenaci Přihod lišky Bystroušky, která vznikla tři roky po pražském uvedení inscenace Felsensteina, formuloval výslovně jako polemiku s koncepcí tohoto operního režiséra.

73 Ve své autobiografii se zmínil, že když naopak Felsenstein osobně zhlédl jeho inscenaci Př́hod lišky Bystroušky v Národním divadle (1954), prohlásil, že takové pojetí odporuje „správnému“ inscenačnímu př́istupu k Janáčkově opeře (KAŠLÍK 1987: 57). 
o to více však podtrhl poetický rozměr a snovou atmosféru lesa, naznačeného za pomoci soustavy abstraktních tvarů. Ve spolupráci s výtvarníkem využil bohatých kinetických možností brněnského, tzv. nového Janáčkova divadla, jež touto inscenací vstoupilo do první sezony existence. Akce živých herců na scéně se důmyslně prolínala s hrou projekcí a dalších světelných efektů. ${ }^{74}$ Scénicky tedy Wasserbauer pojednal inscenaci mnohem odvážněji než jeho německý kolega a ani on se nevyhnul hlubším úpravám, z hlediska dosavadní janáčkovské inscenační praxe málo obvyklým. Oproti Felsensteinovi se ale snažil, aby zbavil Janáčkovu operu všeho nadbytečného. Jeho nejvážnější zásah spočíval v redukci zvírecích postav, z nichž ponechal pouze ty, jež jsou důležité pro dramatický děj. Za zvláště diskutabilní považovali recenzenti eliminaci baletu (výstupy vážky a mušek, svatební rej).

Pátráme-li v českém operním divadle 60. let po režisérovi, který nejvíce reagoval na Felsensteinův koncept hudebního divadla, pak to byl dozajista právě Miloš Wasserbauer. Vztah Wasserbauera k práci Waltera Felsensteina lze charakterizovat podobností tvůrčích názorů a samotných východisek tvorby. Není možné konstatovat, že by se Wasserbauer př́imo a záměrně Felsensteinovou tvorbou zásadním způsobem inspiroval. Spíše na ni ve své inscenační i teoretické praxi reagoval, a to v mnohém právě přes dobový kontext, v němž Felsensteinova tvorba rezonovala. Rozhodně nešlo o nadšené následování Felsensteinových režijních postupů či snahu vyrovnat se jejich povaze či úrovni. ${ }^{75}$ Wasserbauer stavěl vždy před režiséra jako hlavní úkol přiblížit operní dílo modernímu diváku, přičemž rád akcentoval společensko-politickou rovinu příběhu a hledal způsoby jejího jevištního vyjádření (v Brně v 60. letech naplňovala opera program sociálně angažované tvorby souběžně s činohrou). Nikdy nepřestal směřovat $\mathrm{k}$ realistickému divadlu a Felsenstein mu v dobovém evropském kontextu logicky představoval orientační bod, od něhož odvíjel své představy o podobě operní inscenace. Je třeba zdůraznit, že žádný jiný český operní režisér té doby se operou nezaobíral tak do hloubky a s takovým zaujetím pro teoretické otázky jako Wasserbauer. Nevíme, jakými cestami se k Felsensteinovu teoretickému dílu dostal, ale jeho úvahy o opeře a otázkách operní dramaturgie a inscenace svědčí o tom, že myšlenkový odkaz německého režiséra studoval a nechal se jím ve svých vlastních vyjádřeních inspirovat. Hlásil se už k Felsensteinově výchozí tezi, že opera nesmí být „kostýmovaným koncertem“, že je třeba usilovat o její „zdivadelnění“. ${ }^{76}$ Také Wasserbauer zdůrazňoval, že inscenační záměr se musí podřídit partituře (sám přitom reprezentoval typ režiséra, který v samostatném domýšlení partitury zacházel ve své době nebývale daleko a se skladatelovým záměrem se dostával až do sporu). Stejně tak přijal za svou vlastní

74 Popisem výtvarného a celkově inscenačního řešení opery v režii Miloše Wasserbuera se zabývala ve své diplomové práci Dana Toncrová (TONCROVÁ 2000: 62-73).

75 Na Wasserbauerův spíše odmítavý postoj k práci rakouského režiséra upozornila Eugenie Dufková, která v jednom z rozhovorů se Šárkou Havlíčkovou Kysovou parafrázovala Wasserbauerova slova, jimiž se o svém vztahu k tvorbě Waltera Felsensteina vyjádřil. (Rozhovor Šárky Havlíčkové Kysové ze dne 16. 3. 2016, audionahrávka, uložena v soukromém archivu $\check{S} H K$.)

76 „Vysoce vyzvedávám zásluhu Waltera Felsensteina o zdivadelnění opery a v tomto bodě jdu s ním společnou cestou.“ WASSERBAUER, Miloš. Interpretace opery, jak já ji cítím a jak se o ni pokouším. Rkp. [1], soukromý archiv Aleny Mášové. Cit. dle (TONCROVÁ 2000: 17). 
Felsensteinovu premisu, že hlavními nositeli hudebně divadelního zážitku musí být „operní herci“, 77 a i on považoval v rámci scénické interpretace opery za nejdůležitější, aby režisér spolu se zpěváky dosáhl „vnitřní pravdivosti“ a „přirozenosti“ v jednání postav. ${ }^{78}$ Pojem realismus chápal tak jako Felsenstein v širším slova smyslu - nikoli tedy jako označení stylu, nýbrž ve významu obsahové hodnověrnosti a přesvědčivosti. Současně ale dodával, že scénická interpretace opery působí až tehdy „pravdivě“ a „přirozeně“, když režisér dosáhne jednoty jevištního výrazu s výrazovými prostředky dané opery. Jinak řečeno: režisér podle něj musí vycházet z charakteristického slohu inscenovaného díla, který mu určí míru jevištního realismu, resp. stylizace. ${ }^{79}$ A právě v tomto bodě vstupoval s Felsensteinem do neskrývané polemiky. ${ }^{80}$ Wasserbauer uváděl např́́klad jako nezbytné dodržet v inscenacích starších oper dualismus recitativu (s jeho dynamičností) a árie, vyznačující se naopak statičností. (V inscenaci Myslivečkova Tamerlána z roku 1967 nechal árie zpívat na malém stupínku nejblíže publiku a doprovodit je sošnými gesty interpretů, recitativním výstupům, které výrazně rozehrál po pohybové stránce, naopak ponechal celou plochu scény.) ${ }^{81}$ Nejblíže ale měl tento režisér k opeře 20. století, snad proto, že nejvíce souzněla s moderním jevištním výrazem, který svým inscenacím s pomocí soudobých uměleckých i technických prostředků scény dokázal vtisknout. Pokud šlo o herectví, nepřestával Wasserbauer nikdy operovat s představou psychologické charakteristiky ve ztvárnění postavy, jakkoli opět zdůrazňoval, že „sloh skladatelský je [...] určovatelem i formy jevištního projevu herce [... ] inspirací k domyšlení, k dotvoření, k nalezení ,was ungesagt ist‘,

77 „Považuji herce a jeho pravdivé herectví v opeře za jádro, za samu podstatu operní interpretace.“ Cit. dle (TONCROVÁ 2000: 17).

78 V Poznámkách pro sólisty inscenace Síly osudu G. Verdiho v Lipsku, které Wasserbauer sepsal roku 1963 u prŕíležitosti svého hostování jako režiséra v lipské Opeře, uváděl, že v „realistických inscenacích“ má být nejdůležitějším prostředkem režiséra jednání herců na scéně: „Ti jsou hlavními nositeli působení díla na diváka a z míry pravdivosti pocitů a myšlenek, které jsou vyjádřeny jako dramatické ztvárnění díla, z míry věrohodnosti jejich vzájemných vztahů a vztahů k prostředí, ze správného jednání postav, [...] se odvíjí síla realistického působení na publikum." Strojopis [1], pozůstalost Miloše Wasserbauera v divadelním oddělení Moravského zemského muzea v Brně, nesign. Wasserbauerův text, z nějž citujeme, je jasným dokladem toho, že byl poučeným čtenářem Felsensteinových úvah o hudebním divadle. Oba režiséři se znali, Wasserbauer Felsensteinovu tvorbu sledoval a zjevně mu záleželo na tom, aby jeho německý kolega inscenaci Sily osudu zhlédl. Svědčí o tom dopis, který slavnému režisérovi 4. 9. 1963 adresoval z Lipska v době zkoušek právě na tuto inscenaci (Felsensteina v něm mj. ujištuje, že se chystá navštívit nějaké jeho představení v berlínské Komické opeře). V pozůstalosti se dochovala i Felsensteinova odpověd’ z 11. 9. t. r., zvoucí českého kolegu na premiéru Rytíre Modrovouse.

79 „Odraz životní skutečnosti je v každém umění jen tehdy pravdivý, je-li vyjádřen uměleckými prostředky. Tyto umělecké prostředky - formu, styl - volí sám tvůrčí umělec, hudební dramatik. Z nich pak nutně musí vycházet forma a styl scénické reprodukce, za něž je odpověden operní režisér. Nejsou-li tyto prostředky v dokonalém souladu a pravdivé závislosti na hudebních vyjadřovacích prostředcích skladatelových, nemůže scénická interpretace díla působit pravdivě a přirozeně.“ (WASSERBAUER 1957: 211)

80 Režisérka Alena Vaňáková, která léta působila jako Wasserbauerova asistentka, uvedla, že Wasserbauer u Felsensteina postrádal různorodost inscenačního přístupu. Vadilo mu, že ve scénickém zpracování nebral ohled na specifičnost kompozičního zpracování a umělecký styl doby, v níž bylo dílo vytvořeno. V jeho pohledu byl Felsensteinův Mozart prý stejný jako Verdi. (Rozhovor Heleny Spurné s Alenou Vaňákovou ze září 2016, audionahrávka, uloženo v soukromém archivu $H S$ ).

81 Blíže o této inscenaci viz (ŠALDOVÁ 2005: 47). Zde též seznam recenzí k uvedené inscenaci Tamerlán. 
řečeno s Felsensteinem. "82 Jeho inscenace jsou dokladem, že tak jako vesměs všichni čeští operní režiséři šedesátých let, usiloval i on o dosažení psychologicky věrohodné postavy, tu s větší, tu s menší mírou pohybové stylizace.

Co se týče integrování vlivu Stanislavského do vlastní tvůrčí práce, ve srovnání s Felsensteinem se odkazy na Stanislavského systém výchovy herce pravidelně objevují jak v reflexích Wasserbauerovy operně režijní tvorby, tak v jeho vlastních textech. Jde povětšinou spíše o zmínky či pasáže drobného rozsahu, které čtenáři nijak systematicky neozřejmují podstatu této metody a mnohdy ani nejsou př́liš konkrétní, pokud jde o postupy, jež jsou od Stanislavského přejímány. O něco obsáhleji a konkrétněji než recenzenti se o své tvưrčí metodě v souvislosti s postupy Stanislavského vyjadřuje Wasserbauer sám. Činí tak především ve spojitosti s inscenacemi Mladé gardy (1951) a Tarasovy rodiny (1952), zejména když hovoří o pečlivém studiu využívajícím pomocného a historického materiálu při práci na inscenaci atp. Lze souhlasit s názorem Dany Toncrové, která vysvětluje, že Wasserbauer prohlašoval za východisko své práce s hercem postupy Stanislavského „[n]epochybně pod vlivem obecných tendencí zkreslených výkladů systému Stanislavského a jejich aplikace na činohru, operu, balet nebo loutkové divadlo“ (TONCROVÁ 2000: 13).

Otázkou samozřejmě zůstává, do jaké míry si byl Wasserbauer vědom zkreslenosti obecného povědomí divadelníků jeho doby, a tedy i jeho samotného, o systému Stanislavského. Nelze bohužel jednoznačně určit, kde čerpal své poznatky o této metodě. Ve svých odkazech na Stanislavského a stručných popisech konkrétních postupů, které z jeho systému přebíral, lze Wasserbauerův postoj $\mathrm{k}$ této koncepci tvorby charakterizovat jako vědomě inspirovaný a selektivně přijímaný vliv na vlastní režijní práci. Ostatně Wasserbauer opakovaně vyjadřoval nevưli vůči mechanickému či direktivně důslednému aplikování této (či snad jakékoliv) metody na vlastní práci, bez promýšlení a připouštění hledání nových postupů. Není proto zřejmě tak zásadní se ptát, jak dobře byl Wasserbauer seznámen se Stanislavského pojetím herecké tvorby. Důležité je především to, co si pod pojmem „Stanislavského metoda“ představoval, tj. co proklamativně považoval za metody své vlastní tvorby a čím z toho se řídil. V kontextu přístupu Stanislavského tvorby pak je třeba pouze identifikovat konkrétní styčné body Wasserbauerovy práce s jeho ruským „vzorem“.

Dana Toncrová pojmenovala některé aspekty, v nichž se Wasserbauer inspiroval u Stanislavského (TONCROVÁ 2000). Předně šlo o onu „pravdivost“ v oblasti zobrazení umělecké skutečnosti, jímž byla charakterizována tehdejší realistická interpretace operního díla na scéně, dále „služba“ režiséra autorovi, hledání a zprostředkování ústřední ideje díla, související s oním „proč“ autor dílo psal, jak Wasserbauer často uvádí, či jak to formuluje Toncrová - „pojetí herce jako ústředního nositele významových kvalit díla“ (TONCROVÁ 2000: 14). K těmto postupům samozřejmě patří i pečlivá příprava členů inscenačního týmu včetně herců, pojatá jako důkladné studium doprovodného a historického materiálu a kladení důrazu na kolektivní práci, včetně jejího vzájemně inspirativního a korektivního potenciálu atd.

82 WASSERBAUER, Miloš. Interpretace opery, jak já ji cítím a jak se o ni pokouším. Rkp. [1], soukromý archiv Aleny Mášové. Cit. dle (TONCROVA 2000: 17). 
Navzdory tomu, jaký význam byl Felsensteinově inscenační tvorbě a koncepci hudebního divadla z hlediska vývoje soudobého operního divadla přisuzován, v českém prostředí nebyla přijímána bez výhrad. České operní divadlo čerpalo od šedesátých let podněty i z výrazně odlišných způsobů inscenačního ztvárnění. Jistá část tvůrců, usilujících o obrazně výtvarné vyjadřování, vnímala styl Waltera Felsensteina v podstatě za překonaný. V pražském Národním divadle se projevovala snaha navázat na průbojné kreace Velké opery 5 . května, reprezentované vizuálně osobitými koncepcemi tandemů Václav Kašlík Josef Svoboda a Ladislav Štros - Vladimír Nývlt. Jak Kašlík, tak Štros se vưči Felsensteinovi vymezovali de facto negativně. Kašlík sice nepopíral význam Felsensteinovy metody, kterou spolu s poetikou Wielanda Wagnera a stylem Velké opery 5 . května považoval za nejprůbojnější tendence v operním divadle po roce 1945. S Felsensteinem se ale rozcházel už jen v základním přístupu ke ztvárnění opery na scéně, spočívajícím v akcentaci výtvarné složky, kterou upřednostňoval před hereckou složkou. ${ }^{83}$ Ladislav Štros, ač byl u Felsensteina několik měsíců na stáži, se výslovně bránil tomu, že by od něho „něco odkoukal“. Jedinou inspirací, kterou přiznával, měla být důkladná a intenzivní práce se zpěvákem. Štros však vždycky usiloval o nepsychologické herectví, čímž se vymykal i tehdejší praxi na českých operních scénách: „Na rozdíl od Felsensteina jsem nikdy neusiloval o realistický ba naturalistický styl opery. Naopak jsem směřoval k imaginativnímu odlehčení, k metafoře." (ŠTROS, PETRÁNĚK a JÄGER 2006: 83)

Pokud byl tedy Felsenstein v nějakém ohledu vyzdvihován a dáván bezvýhradně za vzor, pak právě v tom, jak důkladně pracoval s operním zpěvákem a dokázal ho získat pro svou uměleckou vizi. Zmiňme v závěru studie zkušenosti několika českých operních umělců, kteří měli možnost $\mathrm{s}$ Felsensteinem úzce spolupracovat. Když po letech zavzpomínala na své dojmy ze stáže v berlínské Komické opeře režisérka Alena Vaňáková, první, co si vybavila, bylo právě ono pověstné felsensteinovské precizní herectví, režijní maximalismus, dovedený v práci se zpěvákem do krajnosti. ${ }^{84}$ Posedlost detailně vypracovaným herectvím, zvyk zkoušet větu za větou, frázi za frází, takt po taktu tak dlouho, dokud výsledek Felsenstein nepovažoval za jednoznačně přesvědčivý, potvrzuje také Jana Smítková, která vystupovala ve dvou jeho inscenacích. Tato představitelka Káti Kabanové v Herzově inscenaci z roku 1972 připomněla ještě další důležitý aspekt Felsensteinovy inscenační práce, totiž že Felsenstein vždy hledal zpěváka, který nejenže se dokázal po herecké stránce „zmocnit“ jím představované postavy, ale zároveň přesně odpovídal jejímu typu. ${ }^{85}$ Klemens Słowioczek zpíval osm let Figara ve Felsensteinově poslední inscenaci (Figarova svatba) a jak se zmínil, počínání tohoto režiséra na scéně nikdy nepocitoval jako realismus. Z působení v Komické opeře v daném období si odnesl poznatek, že Felsenstein byl mimořádný tím, že dokázal dovést zpěváka do stavu nejvyššího možného porozumění tomu, co zpívá a jak v dané situaci jedná. Podobnou

83 Ve své autobiografii se nazývá „režisérem-inscenátorem“, který vidí hudbu nejprve v obrazech a teprve poté ji překládá do hereckého pohybu a gesta (KAŠLíK 1987: 58).

84 Rozhovor Heleny Spurné s Alenou Vaňákovou ze září 2016 (audionahrávka, uloženo v soukromém archivu $H S$ ).

85 Rozhovor Heleny Spurné s Janou Smítkovou z listopadu 2016 (audionahrávka, uloženo v soukromém archivu $H S$ ). 
zkušenost pak už Słowioczek učinil pouze sporadicky. ${ }^{86}$ Je možné, že právě ve schopnosti přivést interpreta ke smyslu díla a pomoci mu nalézt způsob vyjádření, jímž by se toto dílo pro diváka stalo důvěrně blízkým, spočívá hlavní přínos Waltera Felsensteina opernímu divadlu.

\section{Bibliografie}

ANTAROWA, Konkordija. 1951. Studioarbeit mit Stanislawski. Dreißig Gespräche über System und Elemente schöpferischer Arbeit und fünf Gespräche über die Arbeit an der Oper „Werther“ von Massenet. Berlin: Henschel, 1951.

BAJER, Jiří. 1962. Achillova pata Komické opery? [Achilles' Heel of the Comic Opera?]. Divadelni noviny 5 (1962): 23: 8.

BOR, Vladimír. 1962. Bystrouška v berlínském podání [The Cunning Little Vixen in Berlin Production]. Lidová demokracie (31. 5. 1962).

BOR, Vladimír. 1962. Komická opera zahájila Othellem [The Comic Opera Opened With Othello]. Lidová demokracie (26. 5. 1962).

BROŽOVSKÁ, Jarmila. 1956. Felsensteinovy inscenace v Praze [Felsenstein's Productions in Prague]. Divadlo 7 (1956): 7: 597-601.

BROŽOVSKÁ, Jarmila. 1959. Zápas o pravdu v opeře [Fight for the Truth in Opera]. Divadlo 10 (1959): 10: 780-788.

BROŽOVSKÁ, Jarmila. 1962. Komická opera a my [The Comic Opera and Us]. Kultura VI (1962): 22: 4 .

BROŽOVSKÁ, Jarmila. 1965. O současné operní inscenaci [On the Current Opera Productions]. Mladá fronta (21. 11. 1965).

BROŽOVSKÁ, Jarmila. 1966. Musiktheater - současné operní divadlo? [Musiktheater - A Current Opera Theatre?]. Divadlo 17 (1966): 2: 76-78.

BURIAN, Karel Vladimír. 1979. Walter Felsenstein. Praha: Supraphon, 1979.

FELSENSTEIN, Walter. 1956. Příspevěk k diskusi o hudebním divadle [To the Discussion of Music Theatre]. Divadlo 7 (1956): 7: 602-603.

FELSENSTEIN, Walter a Siegfried MELCHINGER. 1964. Hudobné divadlo [The Music Theatre]. Bratislava: Štátne hudobné vydavatel'stvo, 1964.

FELSENSTEIN, Walter, Götz FRIEDRICH a Joachim HERZ. 1970. Musiktheater. Beiträge zur Methodik und zu Inszenierungs-Konzeptionen (hg. von Stephan Stompor). Leipzig: Philipp Reclam, 1970.

FELSENSTEIN, Walter. 1976. Schriften zum Musiktheater (hg. von Stephan Stompor). Berlin (DDR): Henschel, 1976.

FELSENSTEIN, Walter. 1991. Theater. Gespräche, Briefe, Dokumente (hg. von Ilse Kobán). Berlin: Edition Hentrich, 1991.

HERRMANNOVÁ, Eva a Vladimír LÉBL. 1962. Janáček, Felsenstein a Komická opera [Janáček, Felsenstein, and the Comic Opera]. Literárni noviny XI (1962): 23: 1 a 3.

86 Rozhovor Heleny Spurné s Klemensem Słowioczkem z listopadu 2016 (audionahrávka, uloženo v soukromém archivu $H S$ ). 
HINTZE, Werner, Clemens RISI a Robert SOLLICH (Hrsg.). 2008. Realistisches Musiktheater. Walter Felsenstein: Geschichte, Erben, Gegenpositionen. Berlin: Theater der Zeit (Recherchen 51), 2008.

KAŠLÍK, Václav. 1987. Jak jsem dèlal operu [How I Staged Opera]. Praha: Panton, 1987.

KEHRMANN, Boris. 2015. Vom Expressionismus zum verordneten „Realistischen Musiktheater“. Walter Felsenstein - Eine dokumentarische Biographie 1901 bis 1951. [Dresdner Schriften zur Musik. Hochschule für Musik Carl Maria von Weber Dresden, hg. von Matthias Herrmann), Bd. 3, 2 Teile]. Marburg: Tactum, 2015.

KRISTI, Grigori W. 1954. Stanislawskis Weg zur Oper. Berlin: Henschel, 1954.

KRIŠKA, Branislav. 1970. Režisér - autorita - tradícia [Theatre Director, Authority, and Tradition]. Hudobný život II (1970): 21 (6. 11. 1970): 1 a 8.

PACLT, Jaromír. 1959. Felsensteinův Othello [Felsenstein's Othello]. Divadelni noviny 3 (1959/60): $4: 8$.

PEČMAN, Rudolf. 1962. Felsensteinova koncepce opery [Felsenstein's Concept of Opera]. Host dо dоти IX (1962): 7: 323.

PEČMAN, Rudolf. 1966. Hudební divadlo k diskusi [Music Theatre in Discussion]. Věda a život (1966): 3: 191-192.

PEČMAN, Rudolf. 1977. Principy hudebního divadla a interpretační styl oper Janáčkových (Kritická retrospektiva jako podnět k zamyšlení) [Principles of Music Theatre and the Interpretation Style of Janáček's Operas. Critical Retrospect as an Impuls for Rethinking]. Program Státního divadla Brno XLVII (1977): 9: 315-320.

PROCHÁZKA, Jaroslav. 1962. Dvakrát s Waltrem Felsensteinem [Walter Felsenstein Twice]. Divadelni noviny 5 (1962): 16-17: 8.

STANISLAVSKIJ, Konstantin Sergejevič. 1954. K. S. Stanislavskij o operním divadle [Stanislavski on the Opera Theatre]. Sovětské divadlo IV (1954): 3: 295-301.

SYCHRA, Antonín. 1962. Nad tvorbou W. Felsensteina [Notes to W. Felsenstein's Work]. Tvorba 27 (4. 7. 1962): 23: 538-539.

ŠALDOVÁ, Lenka. 2005. Česká operni režie v šedesátých letech 20. století [Czech Opera Direction of the 1960s]. Disertační práce [Dissertation Thesis]. Praha. Univerzita Karlova. Filozofická fakulta [Charles University, Faculty of Arts].

ŠEFL, Vladimír. 1962. Komická opera a opera [The Comic Opera and the Opera]. Hudebni rozhledy 15 (1962): 13: 540-542.

ŠTROS, Ladislav. 1995/96. Jak jsem v Praze inscenoval Janáčka [How I Staged Janáček in Prague]. Opera. Informační zdroj SOP (1995/96): 3 (26): 23-24.

ŠTROS, Ladislav, Pavel PETRÁNĚK a Daniel JÄGER. 2006. Má cesta operou [My Operatic Journey]. Praha: Národní divadlo, 2006.

TONCROVÁ, Dana. 2000. Miloš Wasserbauer a jeho hledáni realistické scénické interpretace v opeře (Tuorba Miloše Wasserbauera ve Státním divadle Brno v letech 1958-1970) [Miloš Wasserbauer and His Strive for the Realistic Scenography in Opera. Miloš Wasserbauser's Work in the State Theatre in Brno, 1958-1970]. Diplomová práce [Diploma Thesis]. Brno. Masarykova univerzita. Filozofická fakulta [Masaryk University, Faculty of Arts].

iv [VOJTĚCH, Ivan]. 1962. Dilema operního herectví. Felsenstein 1962 [Dillema of Operatic Acting. Felsenstein 1962]. Divadlo 13 (1962): 7: 52-53.

WASSERBAUER, Miloš. 1957. Princip realistické scénické interpretace v opeře [Principles of the Realistic Scenography in Opera]. Divadlo 8 (1957): 3: 211-214. 


\section{Mgr. Šárka Havlíčková Kysová, Ph.D.}

Katedra divadelních studií, Filozofická fakulta, Masarykova univerzita sarka.havlicek@mail.muni.cz

Šárka Havličková Kysová získala titul Ph.D. na Masarykově univerzitě v Brně v roce 2010, kde obhájila disertační práci s názvem Hastábhinaja. Gesta rukou v tradičním divadelním umění Indie. V letech 2009 až 2012 vyučovala teorii divadla na Katedře divadelních, filmových a mediálních studií Univerzity Palackého v Olomouci. V letech 2011 až 2015 se podílela na Masarykově univerzitě na řešení dvou projektů; 'Český divadelní strukturalismus: souvislosti a potenciál' a 'Operační program vzdělávání pro konkurenceschopnost - 2.2 Vysokoškolské vzdělávání'. Od roku 2012 pracuje jako odborná asistentka na Katedře divadelních studií Masarykovy university. Ve svém výzkumu i v pedagogické činnosti se zaměřuje na teorii divadla se zvláštním zřetelem k možnosti uplatnění kognitivních teorií v teatrologii. Zabývá se také inscenační praxí opery a tradičním indickým divadlem kúdijáttam. Od roku 2015 vede výzkumný projekt s názvem 'Generace režiséra Miloše Wasserbauera a progresivní dramaturgie v opeře Státního divadla v Brně', který je zaměřen na výzkum operní inscenační praxe ve druhé polovině 20. století (projekt GAČR, GA15-06548S).

Šárka Havlíčková Kysová received her PhD from Masaryk University, Brno in 2010 with the doctoral thesis Hastaabhinaya. Hand gestures in traditional theatre art of India. From 2009 to 2012 she taught theatre theory at Palacký University in Olomouc. From 2011 to 2015 she worked on two Masaryk University research projects; 'Czech Structuralist Thought on Theatre: Context and Potency' and 'Operational Programme Education for Competitiveness - 2.2 Higher Education'. Since 2012 she has worked as assistant professor at the Department of Theatre Studies at Masaryk University. In her research and teaching, she focuses on theatre theory with an emphasis on the cognitive approach in theatre studies. She also specialises in opera staging and the traditional Indian theatre form - Kootiyattam. Since 2015 she has lead the research project 'Generation of Miloš Wasserbauer, the theatre director, and progressive dramaturgy of State Theatre in Brno' which is focused on operatic productions in Brno in the second half of the 20th century (supported by the Czech Science Foundation project No. GA15-06548S). 


\section{Mgr. Helena Spurná, Ph.D.}

Katedra divadelních a filmových studií, Filozofická fakulta, Univerzita Palackého helena.spurna@upol.cz

Mgr. Helena Spurná, Ph.D. (1970) v roce 1999 obhájila na Masarykově univerzitě v Brně dizertační práci Mezi hudbou a divadlem. K problematice hudebně divadelní tvorby E. F. Buriana. $\checkmark$ letech 1999-2001 působila jako odborná asistentka na Ústavu divadelní vědy (dnes Katedra divadelních studií) téže univerzity. Poté přešla na Katedru divadelních a filmových studií Univerzity Palackého v Olomouci, kde působí dodnes. Vyučuje dějiny divadla, badatelsky se zaměřuje na výzkum moderního českého divadla včetně divadla hudebního. Je editorkou ceněného souboru textů Hudební divadlo jako výzva (Praha: Národní divadlo, 2004) a autorkou dvou samostatných monografií: Emil František Burian a jeho cesty za operou (2014) a Divadelní režisér a člověk Oldřich Stibor (1901-1943).

Helena Spurná (1970) graduated from Masaryk University, Brno (CZ) in 1999 (dissertation: Between Music and Theatre. Emil František Burian's Musical Theatre). She worked as an Assistant Professor at the Department of Theatre Studies of the said university from 1999 to 2001. From then on, she has a position at the Department of Theatre and Film Studies, Faculty of Arts, Palacký University, Olomouc (CZ), teaching Theatre History. She researches into Czech Modern Theatre, especially the Music Theatre. She edited a highly appreciated collection the Music Theatre as a Challenge (Praha: Národní divadlo, 2004), and authored two monographs, Emil František Burian and His Journey to Opera (2014) and Oldrich Stibor, Theatre Director and a Person (1901-1943). 
